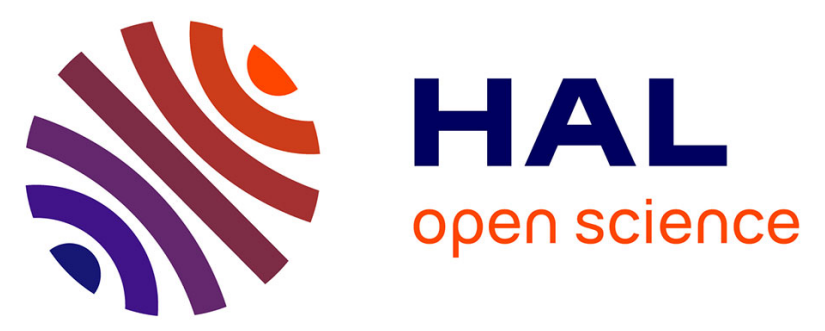

\title{
Effect of in vivo chronic exposure to clotrimazole on zebrafish testis function
}

\author{
Damien Baudiffier, Nathalie Hinfray, Catherine Ravaud, Nicolas Creusot, \\ Edith Chadili, Jean-Marc Porcher, Rüdiger W. Schulz, François Brion
}

\section{- To cite this version:}

Damien Baudiffier, Nathalie Hinfray, Catherine Ravaud, Nicolas Creusot, Edith Chadili, et al.. Effect of in vivo chronic exposure to clotrimazole on zebrafish testis function. Environmental Science and Pollution Research, 2013, 20 (5), pp.2747-2760. 10.1007/s11356-013-1474-7 . ineris-00961800

\section{HAL Id: ineris-00961800 \\ https://hal-ineris.archives-ouvertes.fr/ineris-00961800}

Submitted on 20 Mar 2014

HAL is a multi-disciplinary open access archive for the deposit and dissemination of scientific research documents, whether they are published or not. The documents may come from teaching and research institutions in France or abroad, or from public or private research centers.
L'archive ouverte pluridisciplinaire HAL, est destinée au dépôt et à la diffusion de documents scientifiques de niveau recherche, publiés ou non, émanant des établissements d'enseignement et de recherche français ou étrangers, des laboratoires publics ou privés. 
2

3

$4 \quad$ Marc $^{1}$, Schulz Rüdiger ${ }^{2}$, Brion François ${ }^{1^{*}}$

5

6

$7 \quad$ Halatte, France

$8{ }^{2}$ University of Utrecht, Science Faculty, Department Biology, Division Developmental Biology,

9 Reproductive Biology Group, Padualaan 8, NL-3584 CH Utrecht, Netherlands.
10

11

12

13

14

Corresponding author:

Dr François Brion

INERIS, Direction des risques chroniques, Pôle VIVA, Unité d'écotoxicologie in vitro et in vivo, Parc

Technologique Alata, BP2, 60550 Verneuil-en-Halatte, France

Phone : +33-3 44556512

Fax : +33-3 44556605

Email : francois.brion@ineris.fr 1 


\section{Abstract}

32

Clotrimazole is an azole fungicide used as a human pharmaceutical that is known to inhibit cytochrome P450 (CYP) enzymatic activities, including several steroidogenic CYP. In a previous report, we showed that a 7 days exposure to clotrimazole induced the expression of genes related to steroidogenesis in the testes as a compensatory response, involving the activation of the Fsh/Fshr pathway. In this context, the aim of the present study was to assess the effect of an in vivo 21 -d chronic exposure to clotrimazole $(30-197 \mu \mathrm{g} / \mathrm{L})$ on zebrafish testis function, i.e. spermatogenesis and androgen release. The experimental design combined (i) gene transcript levels measurements along the brain-pituitary-gonad axis (ii) 11-ketotestosterone quantification in blood and (iii) histology of the testes, including morphometric analysis. The chronic exposure led to an induction of steroidogenesis-related genes and $f s h r$ in the testes as well as $f \operatorname{sh} \beta$ in the pituitary. Moreover, increases of the gonado-somatic index and of the volume proportion of interstitial Leydig cells were observed in clotrimazoleexposed fish. In accordance with these histological observations, the circulating concentration of 11-KT had increased. Morphometric analysis of the testes did not show an effect of clotrimazole on meiotic (spermatocytes) or postmeiotic (spermatids and spermatozoa) stages, but we observed an increase in the number of type A spermatogonia, in agreement with an increase in mRNA levels of piwill, a specific molecular marker of type A spermatogonia. Our study demonstrated that clotrimazole is able to affect testicular physiology and raised further concern about the impact of clotrimazole on reproduction.

Keywords: clotrimazole, endocrine disruption, spermatogenesis, steroidogenesis, HPG axis, zebrafish 


\section{Introduction}

Spermatogenesis is a cyclic and tightly regulated developmental process during which a small number of spermatogonial stem cells proliferate and differentiate to form a large number of spermatozoa (Nobrega et al. 2009; Schulz et al. 2010). Germ cells can only survive and develop in close and continuous relationship with Sertoli cells (Matta et al. 2002). Spermatogenesis is supported by testicular steroidogenesis, a multi-step process involving a cascade of enzymatic reactions and producing steroid hormones (Miller 1988; Parker and Schimmer 1995) that control various physiological functions (Miller 1988). Spermatogenesis and steroidogenesis are under control of the hypothalamus-pituitary-gonad (HPG) axis: hypothalamic gonadotropin-releasing hormone (GnRH) stimulates the release of pituitary gonadotropins, luteinizing hormone (Lh) and follicle-stimulating hormone (Fsh), that interact with their gonadal G protein-coupled receptors, Fsh receptor (Fshr) and Lh receptor (Lhcgr). Androgenic sex steroids synthesized in Leydig cells in response to gonadotropic stimulation interact with the androgen receptor (Ar) expressed by Sertoli or interstitial somatic cells in the testis (Burns and Matzuk 2002; Kumar 2005; Petersen and Soder 2006; Pierce and Parsons 1981). In fish, testicular expression sites of gonadotropin receptors overlap in Sertoli and Leydig cells (Garcia-Lopez et al. 2009; Ohta et al. 2007) and Fsh is a potent steroidogenic hormone (Kazeto et al. 2008; Planas et al. 1993). Follicle stimulating hormone activates the Fshr on Leydig and Sertoli cells to control steroidogenesis and spermatogenesis, respectively (Garcia-Lopez et al. 2009; Garcia-Lopez et al. 2010; Ohta et al. 2007; Schulz et al. 2010). In male fish, Leydig cells produce11oxygenated androgens, such as 11-ketotestosterone (11-KT), which stimulates spermatogenesis (Miura et al. 1991). Sertoli cells but not germ cells expressed functional receptors for both androgens and Fsh, so these cells act as regulatory interface between the endocrine system and the germ cells (Petersen and Soder 2006).

Azole fungicides inhibit cytochrome P450 (CYP) 51, 14 $\alpha$-lanosterol demethylase, disrupting ergosterol synthesis and increasing cell permeability in fungi (Georgopapadakou 1998; Henry and Sisler 1984). Several azole fungicides such as ketoconazole or prochloraz also inhibit other CYP enzyme activities and have the capacity to alter gonadal steroidogenesis and reproductive function in fish (Ankley et al. 2007; Villeneuve et al. 2007a; Zhang et al. 2008a). For example, several azole compounds inhibit steroidogenic cytochrome P450 17 $\alpha$ hydroxylase/17,20-lyase (Cyp17) and aromatase (Cyp19) in mammals and fish (Ayub and Levell 1987; Heneweer et al. 2004; Hinfray et al. 2006b; Monod et al. 1993; Vinggaard et al. 2000). Data on the occurrence and fate of azole fungicides in the aquatic environment are scarce although the concentrations of several azoles such as clotrimazole, propiconazole, fluconazole and tebuconazole have been reported at concentrations ranging 
from the low ng/L to the low $\mu \mathrm{g} / \mathrm{L}$ range (Berenzen et al., 2005; Kahle et al., 2008; Kreuger, 1998; Peschka et al., 2007; Roberts and Thomas, 2006; Thomas and Hilton, 2004). Despite their occurrence in aquatic habitat, there exist very few studies on their in vivo endocrine-disrupting potencies in fish (Brown et al., 2011; Hinfray et al., 2011).

In a previous short-term experiment of 7 days, we investigated the effect of clotrimazole on the pituitary-gonad axis at the molecular level in adult male zebrafish. Our data showed that clotrimazole induced a biological compensation as revealed by increased expression of steroidogenesis-related genes and protein de novo synthesis in Leydig cells while the 11-KT plasma concentration was not affected. Clotrimazole exposure also induced over-expression of pituitary $f \operatorname{sh} \beta$ and its testicular receptor $f s h r$. These results suggested that Fsh/Fshr signalling is involved in the clotrimazole-induced steroidogenesis (Baudiffier et al. 2012; Hinfray et al. 2011). Moreover, this raised the question if also spermatogenesis, a process regulated by androgens and Fsh (McLachlan et al. 2002; Plant and Marshall 2001; Schulz et al. 2010), would be affected by clotrimazole.

Therefore, the present study aimed at assessing the effect of a prolonged in vivo exposure of fish to clotrimazole on steroidogenesis and spermatogenesis, addressing the following questions: (i) Does biological compensation in response to inhibiting enzymatic activities still occur after a prolonged 21-d exposure of male fish to clotrimazole at similar concentrations as those previously used for the 7-d exposure experiment? (ii) Does a prolonged exposure have a significant effect on spermatogenesis? 


\section{Methods}

The experimental design and most of the biological analyses have been described in a previous study (Baudiffier et al. 2012).

\subsection{Animals and treatments}

All experiments were approved by the ethical committee of the National Institute of Industrial Environment and Risks (INERIS). Wild type adult male zebrafish (Danio rerio, AB strain) were obtained from our breeding units (INERIS, Verneuil-en-Halatte, France). Fish were raised on a 14:10 light:dark cycle in a recirculated water system (Tecniplast, France) at $25.1 \pm 1{ }^{\circ} \mathrm{C}$. Clotrimazole (CLO, purity $\geq 98 \%$ ) was purchased from SigmaAldrich (France) and all the stock solutions were prepared in dimethylsulfoxide (DMSO; Sigma-Aldrich).

Zebrafish were exposed to three concentrations of clotrimazole (30, 67 and $197 \mu \mathrm{g} / \mathrm{L})$ or solvent alone (DMSO, $0.004 \% \mathrm{v}$ : v) for 21 days under semi-static conditions with a total renewal of the contaminated water every days (temperature: $25 \pm 0.7{ }^{\circ} \mathrm{C}$; $\mathrm{pH}: 8.01 \pm 0.37$; conductivity: $374.5 \pm 27.6 \mu \mathrm{S} / \mathrm{cm}$; dissolved oxygen: $5.8 \pm 0.8$ $\mathrm{mg} / \mathrm{L}$ ). Each condition contained 21 fish equally distributed in three replicates $4 \mathrm{~L}-$ glass tanks. Water samples were collected from each condition at day 11 and day 18 at the time of water renewal $(\mathrm{t}=0 \mathrm{~h})$ and $24 \mathrm{~h}$ later $(\mathrm{t}=$ 24h).

\subsection{Fish sampling}

At the end of the exposure, fish were sacrificed in ice cold water and blood $(2.5$ or $5 \mu \mathrm{L})$ was collected. Liver, pituitary and brain were removed and preserved in RNA later ${ }^{\mathrm{TM}}$ (Sigma-Aldrich, France) until quantification of gene expression. Testes were removed, weighted and preserved in RNA later ${ }^{\mathrm{TM}}$ (Sigma-Aldrich, France) or fixed in Bouin's fluid for histological and immunohistochemistry experiments. Testis mass was determined to calculate the gonado somatic index (GSI, gonad wet mass/total body wet mass x 100).

\subsection{Measurement of actual clotrimazole concentrations}


The protocol was adapted from (Peschka et al. 2007) as described in (Baudiffier et al. 2012). Briefly, clotrimazole concentrations in control and exposure tanks were determined using solid phase extraction (SPE) followed by high-pressure liquid chromatography (HPLC) coupled to UV-Vis detection. An external calibration was used. The limit of detection (LOD) was $0.3 \mu \mathrm{g} / \mathrm{L}$, the limit of quantification was $1.1 \mu \mathrm{g} / \mathrm{L}$ and the recovery of clotrimazole was higher than $90 \%$ in all the experiments. The coefficient of variation, calculated from two replicates per condition, range from 0.4 to $18 \%$.

\subsection{Gene expression analysis}

Transcript levels of genes along the brain-pituitary-gonad axis were measured, using a combination of genes involved in steroidogenesis and spermatogenesis (table S1). In testis tissue, expression of steroidogenic acute regulatory protein (star); hydroxyl- $\Delta$-5-steroid dehydrogenase, $3 \beta$ - and steroid $\Delta$-isomerase 1 (hsd $3 b 1)$; cytochrome P450, family 17, subfamily A polypeptide 1 (cyp17al); cytochrome P450, family 11, subfamily C, polypeptide 1 (cyp11c1; previously referred to as cyp11b2); hydroxysteroid (11- $\beta$ ) dehydrogenase $3 \mathrm{a}$ (hsd11b3a); cytochrome P450, family 19, subfamily A, polypeptide 1a (cyp19ala); cytochrome P450, family 19, subfamily B, polypeptide 1a (cyp19alb); luteinizing hormone / choriogonadotropin receptor (lhcgr); follicle stimulating hormone receptor $(f s h r)$; were measured. The Sertoli cell markers insulin-like growth factor 3 (igf3), anti-müllerian hormone $(a m h)$ as well as the androgen receptor $(a r)$ and the spermatogonial cell marker piwi-like 1 (piwill) were also quantified. In pituitary tissue, expression of beta sub-unit of luteinizing hormone / choriogonadotropin $(\operatorname{lh} \beta)$ and follicle stimulating hormone $\left(f_{s h} \beta\right)$ were measured. In brain tissue, expression of gonadotropin-releasing hormones 3 (gnrh3) and steroidogenesis-related genes were also assessed. Indeed, in view of the impact of clotrimazole on testicular steroidogenesis, examination of brain steroidogenesis appears interesting to consider. In addition, the expression of drug metabolizing enzyme (DME) genes, such as phase I enzymes, i.e. cytochrome P450, family 1, subfamily A polypeptide 1 (cypla1), cytochrome P450, family 3, subfamily A polypeptide 65 (cyp3a65) or phase II conjugating enzymes, i.e. glutathione S-transferase, alpha-like (gstal) and glutathione S-transferase pi 1 (gstpl) was quantified in the liver (table S1). DMEs, known to be involved in xenobiotic and drug metabolism, are also key enzymes of catabolism for steroid hormones (Lee et al. 2003).

To measure genes expression levels, total RNA was extracted from testis, liver, brain or pituitary using Trizol Reagent (Life Technologies Inc., UK) following the manufacturer's instructions and complementary DNA for the real-time PCR reactions was generated using a Moloney Murine Leukemia Virus reverse transcriptase (M- 
MLV RT, Promega, France). Gene expression was analyzed using an Eppendorf realplex 4 Master cycler ep gradient S (Eppendorf, France) as previously described by Baudiffier et al. (2012). Normalization to total RNA in association with calibration to a gene-specific mRNA standard curve was employed in organs. For RNA normalization, total RNA was previously adjusted at the same concentration using a Nanodrop ND-8000 spectrophotometer (Nanodrop Technologies, Wilmington, DE) for all samples before reverse transcription. Standard curves were generated for each gene, using specific primers and samples amplified by classic PCR. The concentration of these standards was measured using a Nanodrop ND-8000 spectrophotometer and adjusted to a concentration of $10^{-4} \mu \mathrm{g} / \mu \mathrm{l}$ of cDNA and then serially diluted from $10^{-4} \mu \mathrm{g} / \mu \mathrm{l}$ to $10^{-11} \mu \mathrm{g} / \mu \mathrm{l}$. They were run in parallel to the samples to analyse in the rt-PCR to obtain the concentration in $\mu \mathrm{g} / \mu \mathrm{l}$ for each sample from the corresponding Cycle Treshold $(\mathrm{Ct})$ value. This method, excluding housekeeping genes, was described in the literature. Then, a fold change in mRNA was obtained for each gene of clotrimazole-treated fish relatively to the mean value of the control group for the corresponding gene (Huggett et al. 2005; Villeneuve et al. 2007a).

\subsection{Measurement of 11-KT concentrations}

11-Ketotestosterone was quantified in blood samples by means of a competitive ELISA, following the manufacturer's instructions (11-KT EIA Kit, Cayman Chemical Company, U.S.A.). The mean EC50 \pm standard deviation was $8.6 \pm 0.7 \mathrm{pg} / \mathrm{ml}$ ( $\mathrm{n}=6$ independent experiments). The calculated coefficient of variation between assays was $8 \%$, and the detection limit was $2.8 \mathrm{pg} / \mathrm{ml} \pm 0.3 \mathrm{pg} / \mathrm{ml}$.

\subsection{Fluorescent immunohistochemistry and histology}

After fixation in Bouin's fluid, testis were dehydrated in ethanol, cleared in toluene and embedded in paraffin, according to conventional procedures. Samples were sectioned at $5 \mu \mathrm{m}$ (longitudinal sections). Sections were stained with Haematoxylin-Eosin for histology or mounted on gelatine-coated slides and processed for immunohistochemistry.

Fluorescent immunohistochemistry of Cyp17a1 and Cyp11c1 proteins in zebrafish testes has been performed as previously described (Baudiffier et al. 2012; Hinfray et al. 2011). Briefly, sections were dewaxed and rehydrated, and antigens were unmasked. Tissue sections were then incubated for $1 \mathrm{~h}$ in a saturation PBS solution containing $0.2 \%$ Triton $\mathrm{X}-100$ and $1 \%$ milk powder. Incubation with the primary antibody was performed overnight (1:300 with $0.5 \%$ milk powder in PBS) at room temperature. After rinsing, sections were 
incubated for $1 \mathrm{~h} 30$ with a goat anti-rabbit antibody coupled to Alexa fluor 594 (1:200 with 0.5\% milk powder in PBS).

For morphometric analysis, the protocol was adapted from (Feitsma et al. 2007). The mass of germ cells and other components (i.e., somatic cells including Leydig cells, blood and lymphatic vessels, connective tissue and empty spaces) were determined by light microscopy using a 352-intersection grid. Eight fields chosen randomly (3016 points or 8 fields of 352-intersection grid) were scored for each animal. Intersection points over tissue components were classified as being over one of the following cell types: type A spermatogonia, type B spermatogonia, spermatocytes, spermatids, spermatozoa or 'others', as defined above (i.e. Leydig cells, blood vessels etc.). A detailed morphological description allowing the identification of the different germ cell types in zebrafish has been given previously (Leal et al., 2009); cell type identification is mainly based on the changes in the size of the nuclei, the amount of heterochromatin, visibility of nucleoli, and number of cells within a spermatogenic cyst. The scores were first expressed as the volume fraction per testis tissue component. The mass $(\mathrm{mg})$ of each testis component was then determined as the product of the testis mass $(\mathrm{mg}) \mathrm{x}$ volume fraction of spermatogenic parenchyma $(\sim 0.8) \mathrm{x}$ volume fraction of specific tissue component. The volume fraction of spermatogenic parenchyma was used as a correction factor in order to exclude the mass of the testes capsule, the efferent ducts, and connective tissue associated with testes.

The Leydig cell volume fraction was determined by light microscopy using a 713-intersection grid. Eight fields chosen randomly (5704 points or 8 fields of 713-intersection grid) were scored for each animal. Analysis was performed for 5 fish of each condition. Intersection points were classified as being over Leydig cells or not. Results were expressed in percentage of Leydig cells compared to the total number of cells. The mass (mg) of Leydig cells was then determined as the product of the testis mass (mg) x volume fraction of spermatogenic parenchyma $(\sim 0.8) \mathrm{x}$ volume fraction of Leydig cells component. The volume fraction of spermatogenic parenchyma was used as a correction factor in order to exclude the mass of the testes capsule, the efferent ducts, and connective tissue associated with testes.

\subsection{Data analysis}


210 One way analysis of variance (ANOVA) was performed to test for differences between treatments. Then,

211 differences among treatments were determined using a post hoc test (Tukey Honestly Significant Difference).

212 Normality of the data was previously assessed using a Shapiro test and homogeneity of variance was also

213 verified using the Bartlett test. Non-normally distributed data were log-transformed prior to analysis and a

214 nonparametric Kruskal Wallis test, followed by a Multiple Comparison test, was used when data did not meet

215 parametric assumptions. For gene expression analysis in the pituitary, a Mann and Whitney U-test was employed

216 to compare gene expression levels between the highest clotrimazole-exposed fish and the control fish only.

217 Levels of gene expressions were expressed as fold changes relative to the average value of the control. Statistical 218 analyses, including principal component analysis (PCA), were conducted using $\mathrm{R}^{\mathrm{TM}}$ ( $\mathrm{R}$ 2.13.1, software, $\mathrm{R}$

219 development Core Team). All data are presented as mean \pm SEM. Significance level (p) was fixed at 0.05 $(\mathrm{p}<0.05 * ; \mathrm{p}<0.01 * * ; \mathrm{p}<0.001 * * *)$. 


\section{Results}

\subsection{Water chemistry}

Concentrations of clotrimazole measured in water just after adding clotrimazole $(\mathrm{t}=0 \mathrm{~h})$ were 30,67 and 197 $\mu \mathrm{g} / \mathrm{L}$ for the low, medium, and high contaminations, respectively (table 1). Concentrations declined by 32, 17 and $22 \%$, respectively, after $24 \mathrm{~h}(\mathrm{t}=24 \mathrm{~h})$. For each condition, two measurements were performed (at day 11 and day 18). The results showed that the concentrations were stable over time and concentrations of exposure. Control water samples were all below the limit of detection, i.e. $0.3 \mu \mathrm{g} / \mathrm{L}$.

\subsection{Biometric parameters}

No mortality or any abnormal behavior was recorded in control and clotrimazole-exposed groups during the study. Furthermore, no significant differences were measured among groups for body mass or length (table 2). In fish exposed to the highest concentration of clotrimazole, a strong (30\%) and significant increase of the GSI was measured as compared to control fish (table 2).

\subsection{Expression of genes involved in testicular steroidogenesis}

The mRNA levels of steroidogenesis-related genes in testes, i.s. gonadotropin receptors, star and several genes coding for steroidogenic enzymeswere analysed in control and clotrimazole-exposed fish (Fig.1). Among nine genes assayed by Q-PCR, an increase in transcript levels was observed for five genes after 21 days of exposure to the highest concentration of clotrimazole.

242 The expression of $f s h r$ but not of $l h c g r$ was significantly 1.69-fold up regulated at the highest concentration of clotrimazole $(\mathrm{p}=0.0013)$. The levels of star mRNA increased 1.77 -fold relative to the controls $(\mathrm{p}=0.0094)$.

244 Still at the highest concentration, the transcript levels of cyp17al, cyp1lcl and hsd11b3a were up-regulated 2.18-, 2.13- and 1.41 fold, respectively $(\mathrm{p}=0.00001, \mathrm{p}=0.0015, \mathrm{p}=0.0013)$. The expression of $f$ shr was significantly correlated with these steroidogenic-related genes: star (Spearman 's rank correlation coefficient $\mathrm{r}=$ 0.59; $\mathrm{p}<0.001)$, cyp17al $(\mathrm{r}=0.43 ; \mathrm{p}<0.001)$, cyp11cl $(\mathrm{r}=0.53 ; \mathrm{p}<0.01)$ and hsd11b3a $(\mathrm{r}=0.63, \mathrm{p}<0.001)$. Besides, these steroidogenic-related genes were significantly correlated with each other (data not shown) 
suggesting that Fsh coordinates the stimulatory effects of these genes. Interestingly, cyp19ala gene expression was down-regulated at 30 and $67 \mu \mathrm{g} / \mathrm{L}$, and statistical significance was reached in the $67 \mu \mathrm{g} / \mathrm{L}$ clotrimazoleexposed group. However, no effect was observed at the highest concentration.

\subsection{Gene expression in brain and pituitary}

In brain tissue, transcript levels of genes encoding brain steroidogenic enzymes, oestrogen and androgen receptors as well as gnrh3 were compared between control and clotrimazole-exposed groups (table 3). Clear and statistically significant changes in transcript levels were not found for any of the genes at all concentrations of clotrimazole. While a two-fold induction of cyp19ala expression was measured in fish exposed to 30 and 197 $\mu \mathrm{g} / \mathrm{L}$ of clotrimazole, the high variability observed between individuals, may contribute to the lack of statistical significance.

In the pituitary, transcript levels of $f_{s} h \beta$ and $\operatorname{lh} \beta$ were assessed for the $197 \mu \mathrm{g} / \mathrm{L}$ clotrimazole-exposed group and compared to untreated fish. We only assessed gonadotropin gene expression at the highest concentration because we observed a strong and significant induction of the GSI, of several steroidogenesis-related genes, and of $f s h r$ transcript levels in this group. The results showed that $f \operatorname{sh} \beta$ was increased by 3.6-fold, but expression of $\operatorname{lh} \beta$ was unchanged (Fig.2).

\subsection{Cyp17al and Cyp11c1 immunostaining in the testes}

Using specific polyclonal antibodies, fluorescent immunohistochemistry was performed in testis sections after 21 days of exposure to assess the effect of clotrimazole on Cyp17a1 and Cyp11c1 protein occurrence (Fig.3). The two proteins were localized in interstitial Leydig cells and increased immunostaining was observed for both proteins from $67 \mu \mathrm{g} / \mathrm{L}$ of clotrimazole. This increase became very marked at the highest level of clotrimazole treatment $(197 \mu \mathrm{g} / \mathrm{L})$ especially for the Cyp11c1 protein (Fig.3A and .3B). These results are in accordance with the data on cyp17al and cyp11c1 genes expression.

\subsection{1-ketotestosterone concentrations in blood}


Clotrimazole significantly affected blood 11-KT concentrations as compared to the control group (Fig.4). A concentration-dependent increase was measured with a significant effect at the highest concentration of clotrimazole. Moreover, we noticed a higher inter-individual variation in clotrimazole-exposed groups compared to the solvent control group.

\subsection{Expression of spermatogenesis-related genes}

Transcription of genes involved in spermatogenesis was assessed in testes of control and clotrimazole-exposed fish after 21 days of exposure (Fig.5).

The androgen receptor ar that is expressed in Sertoli and interstitial cells but not in germ cells was significantly up-regulated for all clotrimazole treatments with a similar fold induction whatever the exposure concentration. Transcriptional levels of the two Sertoli cells markers amh and igf3 were also examined. Anti-müllerian hormone amh expression was unchanged whereas igf3 expression was induced in the $67 \mu \mathrm{g} / \mathrm{L}$ clotrimazoleexposed group ( $\mathrm{p}=0.02)$ but not at the highest clotrimazole concentration. Finally, transcript level of the spermatogonial marker piwill was significantly up-regulated at the highest clotrimazole concentration (1.38-fold for $197 \mu \mathrm{g} / \mathrm{L})$.

\subsection{Expression of genes involved in the catabolism of steroid hormones}

Transcript levels of different genes encoding for drug metabolizing enzymes (DMEs) were assessed after 21 days of exposure in testis and in liver (Fig.S1, Fig.S2). In the liver, transcriptional levels of phase I DMEs, i.e. cypla and cyp3a65, and of phase II conjugating enzymes, i.e. gstal and gstpl, remained unchanged in clotrimazole-exposed groups compared to the control group (Fig.S1). However, in testis, cyp3a65 expression was significantly up-regulated (Fig.S2).

\subsection{Principal Component analysis (PCA)}

A PCA was performed in order to have an overview of correlations between the different endpoints measured in the testis and in the blood (Fig.6). The factor 1 explained 34.02\% of the data variability whereas the factor 2 
301

302

303

304

305

306

307

308

309

310

311

312

313

314

315

316

317

318

319

320

321

322

323

324

325

326

327

explained $16 \%$ of the data variability. A plot with respect to this two principal components revealed that expression of all endpoints influenced variation in the negative direction along factor 1.Along factor 2, a strong association between several steroidogenesis-related genes involved in androgen synthesis (star, cyp17al and cyp11c1) was observed. This group of genes was closely associated with igf3, a Sertoli cell marker and piwill, a spermatogonia type A marker (Fig.6A). A close association between 11-KT and GSI was also found. These two parameters were significantly affected in the highest clotrimazole-exposed group and increase GSI might be a consequence of elevated 11-KT production Interestingly, genes related to estrogens biosynthesis (i.e., cyp19ala and cyp19alb) and ER-signalling pathway (i.e., esrl, esr2a, esr 2a) were closely associated and located at the opposite side of those related to androgen biosynthesis. The genes involved in the metabolism of xenobiotic and endogenous hormones (cypla and cyp3a65) were closely associated and localized at the opposite from the biological parameters related to androgen synthesis. Although clotrimazole differently affected the expression of genes encoding for gonadotropin receptors, they were closely associated together with androgen receptor and amh, another Sertoli cell marker. A second plot, representing condition of exposures, showed a strong difference between the $197 \mu \mathrm{g} / \mathrm{L}$ clotrimazole-exposed group that influenced variation along factor 1 compared to the other groups including control and the two other clotrimazole-exposed groups (Fig.6B) showing that all the selected genes allowed to discriminate the different treatments to clotrimazole.

\subsection{Histology and morphometric analysis of the testes}

Histological analysis showed an enlargement of the interstitial space in fish exposed to clotrimazole, as indicated by white arrows (Fig.7A, control; Fig.7B, $197 \mu \mathrm{g} / \mathrm{L}$ clotrimazole). Interestingly, morphometric analysis revealed a significant 2-fold increase of Leydig cell mass (Fig.7C). Finally, quantitative morphometric analysis of testis tissue components was realized in the group exposed to $197 \mu \mathrm{g} / \mathrm{L}$ clotrimazole and the control group (seven males for each group). We focused on the highest clotrimazole concentration since it evoked the most clear effects regarding Leydig cells, target gene expression and GSI. In control individuals, the mass of germ cells, i.e. spermatogonia, spermatocytes, spermatids and spermatozoa, agrees with previously reported data in adult male zebrafish (de Waal et al. 2009). In exposed-fish, a significant 2-fold increase of type A spermatogonia (but not type B) was quantified (Fig.7D). 


\section{Discussion}

329

330 The present work investigated the chronic effects of clotrimazole on two related process, testicular

331 steroidogenesis and spermatogenesis, after 21 days of exposure of zebrafish. A biological compensation of the steroidogenic enzymes inhibition by clotrimazole was revealed, with an up-regulation of genes coding for steroidogenic enzymes, pituitary $f_{s} h$, and its testicular receptor $f_{s} h$. This underlines the critical role of the Fsh/Fshr signalling pathway in mediating the effects of clotrimazole on testicular steroidogenesis. In accordance with inducing Leydig cell steroidogenesis and stimulating the Fsh/Fshr pathway, transcript levels of the Sertoli cell genes igf3 and ar were increased, as well as the 11-KT circulating levels. Furthermore, morphometric analysis of the testes demonstrates that spermatogenesis was impacted by clotrimazole as shown by the increase of the mass of type A spermatogonia in clotrimazole-exposed fish, in accordance with the up-regulation of a marker gene for this germ cell type, piwill.

4.1. Chronic exposure to clotrimazole led to activation of Fsh/Fshr signalling and over-compensation of the steroidogenic parameters

In the present study, we investigated the effects of clotrimazole on the brain-pituitary-gonadal axis, in particular the impact on testicular steroidogenesis after 21 days of exposure. We showed that clotrimazole up-regulated the expression of steroidogenesis-related genes (star, cyp17al, cyp11c1). Principal Component Analysis (PCA) revealed that these endpoints were correlated. Cyp17a1 and Cyp11c1 protein expression was also increased in Leydig cells and 11-KT blood levels were elevated. Induction of steroidogenesis-related genes agrees with recent work on adult male fathead minnow or medaka exposed 21 days to azoles, i.e. ketoconazole or prochloraz (Ankley et al. 2007; Villeneuve et al. 2007a). Clotrimazole is known to inhibit several CYP enzyme activities in fish and mammals; including Cyp19 and Cyp17 (Ayub and Levell 1987; Hinfray et al. 2006b; Monod et al. 1993; Schuster 1985). This inhibition of enzymatic activities in testis tissue can lead to reduced 11-KT release, as noticed in an in vitro zebrafish testicular explant culture system (Hinfray et al. 2011). For that reason, stimulation of the steroidogenic system in vivo was interpreted as a biological compensation in response to enzyme inhibition (Ankley et al. 2007; Baudiffier et al. 2012; Hinfray et al. 2006b; Villeneuve et al. 2007b; Zhang et al. 2008a). However, in the present study, we observed an increase of circulating 11-KT concentrations surmounting control levels, suggesting that an exposure to clotrimazole for 21 days led to an over-compensation. 
We postulate that clotrimazole initially depressed plasma androgen levels, provoking a compensatory response via Fsh, including an increased de novo synthesis of steroidogenic enzymes, such that 11-KT blood levels were normal after 7 days of exposure (Baudiffier et al. 2012), but exceeded normal levels after 21 days of exposure (present study). In recent works on adult male fathead minnows exposed for 21 days to ketoconazole or fadrozole, plasma concentration of 11-KT was not affected (Ankley et al. 2007) or induced (Ankley et al. 2002), respectively. In mammals, plasma and intra-testicular concentrations of testosterone were increased following long-term exposure to azoles (table 4). Taken together, these studies and our study suggest that the relationship between azole exposures and final androgen plasma concentrations cannot be predicted easily. This is probably due to the balance between a direct inhibition of enzyme activities and a compensatory response that stimulates testicular steroidogenic gene expression by gonadotropin. The impact of azole on plasma 11-KT may also depend on the biological model, the tested azole, or the exposure conditions (concentration and duration). Furthermore, the 11-KT concentration is a result of its production, degradation, and excretion. So, an important point to consider is steroid hormone degradation (Lou et al. 2004) by DME, expressed in the liver but also in the gonads. For example, in the present study, we observed an induction of cyp3a65 mRNA transcript level in testes of the group exposed to the highest clotrimazole concentration. This increased gene expression could lead to Cyp3a65 enzyme production and influence circulating11-KT concentrations. In addition, we noticed an inhibition of cyp19al aromatase in the testes following clotrimazole contamination whereas expression of other enzymes involved in androgen production was induced, such as cyp17al and cypl1cl. Reduced aromatisation of androgens could contribute to increasing substrate availability for 11-KT synthesis.

The increase in testicular $f s h r$ and pituitary $f s h \beta$ expression is consistent with a compensatory response supporting the role of Fsh/Fshr-signalling in the clotrimazole-induced steroidogenesis, as demonstrated in our previous 7-days experiment (Baudiffier et al. 2012), if the assumed initial decrease of plasma 11-KT concentration would stimulate pituitary Fsh synthesis and release. However, a change in gnrh3 expression, an important regulator of gonadotropin release in teleost species possessing two Gnrh variants (Kobayashi et al. 1997; Steven et al. 2003), was not demonstrated in our study.

As clotrimazole can directly inhibit CYP activities in testes (Ayub and Levell 1987; Hinfray et al. 2006a; Monod et al. 1993), it was also interesting to investigate the effects of clotrimazole on brain steroidogenesis. Indeed, in teleost fish, the brain possesses high aromatase activity (Pasmanik and Callard 1985) due to the strong expression of the cyp19alb gene coding for aromatase B protein in radial glial cells (Forlano et al. 2001; Menuet et al. 2005). Furthermore, a recent study suggested that radial glial cells express the whole set of key 
steroidogenic enzymes necessary to produce active steroids from cholesterol (Diotel et al. 2011). Our data showed that clotrimazole had no effect on expression of steroidogenesis-related genes in brain tissue. However, considering that these genes are expressed in specific area of the brain, we cannot exclude a dilution effect has masked possible, more subtle changes, since mRNA levels were measured in the whole brain. This reasoning also applies to Gnrh-producing neurones, so that mRNA quantification in specific areas of the brain may provide more relevant data in future experiments.

\subsection{Biological relevance of Fsh-drived clotrimazole-disrupted steroidogenesis on spermatogenesis}

In the present study, we assessed the effect of clotrimazole on testicular physiology, i.e. steroidogenesis and spermatogenic function at the histological and molecular level. Morphometric analysis of germ cells showed a significant effect in the number of type A spermatogonia in the $197 \mu \mathrm{g} / \mathrm{L}$ clotrimazole-treated fish compared to control fish. This result is in agreement with the induction of the germ cell marker piwill expression (formerly known as ziwi), which is a component of a germline-specifying structure called nuage and expressed strongly and exclusively in type A spermatogonia of zebrafish (Chen SX et al. in revision). This increase of type A spermatogonia could be related to molecular changes in Sertoli cells, which are in close contact with germ cells and provide physical, nutritional and regulatory support to the developing germ cells (Griswold 1995; Petersen and Soder 2006). It is also of interest to notice that Sertoli cells that express the highest level of ar mRNA, are in contact with early spermatogonia (de Waal et al. 2008). This is consistent with the notion that these Sertoli cells respond to 11-KT, resulting in a stimulation of spermatogonial proliferation and differentiation (de Waal et al. 2008; Miura et al. 2001a; Miura et al. 1991). Furthermore, it has been demonstrated in eel testes that $f s h r$ is expressed in Leydig cells and high Fshr immunoreactivity was found in Sertoli cells surrounding type A and B spermatogonia (Ohta et al. 2007). In the present study, the observed increase in the mass of type A spermatogonia in adult male zebrafish is in agreement with an induction of the $a r$ and $f s h r$ mRNA.

In accordance with an Fsh/Fshr signalling activation, we also observed an induction of igf3, which is under the control of Fsh and androgens in Sertoli cells. Igf3 has been recently discovered in zebrafish, medaka and Nile tilapia and is specifically expressed in gonadal tissue (Wang et al. 2008). Igf3 belongs to insulin growth factor (IGF) family, which is known to stimulate spermatogenesis in vertebrates (Le Roy et al. 1999), including fish (Loir 1999). 
An important result of our study was that morphometric analysis clearly demonstrated an increase in the mass of Leydig cells in clotrimazole-exposed fish. This is in accordance with an increase in circulating 11-KT concentrations and illustrates the stimulation of the steroidogenic system triggered by the Fsh/Fshr pathway. At present, it is not known why elevated Fsh-signalling and androgen levels did not result in an increase in the mass of spermatogonia B, spermatids and spermatozoids. As shown in table 4, an increased mass of interstitial Leydig cell has also been observed in fish exposed to clotrimazole and ketoconazole (Ankley et al. 2007; Brown et al. 2011), but the precise mechanism of action has not been described. It seems reasonable to assume that an increase in Leydig cell volume can partially explain the elevation of circulating 11-KT concentrations, as these cells are responsible for androgen production.

In conclusion, this study showed that expression of steroidogenesis-related genes in testicular tissue remained induced after 21 days of exposure. Induction of $f \operatorname{sh} \beta, f s h r$ and $i g f 3$ is consistent with and activation of Fsh/Fshr signalling in stimulating Leydig cells steroidogenesis. In comparison with 7 days-exposure period to clotrimazole, we observed in the present study an induction of blood 11-KT concentrations after 21 days of exposure. In parallel, an increase of GSI and a duplication of the mass of Leydig cells were observed. This overcompensation was not followed by a drastic adjustment of spermatogenesis as the proportion of most germ cells remained largely unchanged, except for an increase in the early spermatogonial generations. This study highlights the relevance of studying a network of functional genes along the brain-gonad axis in parallel with histological analysis at the testicular level to study the effect of clotrimazole as an endocrine disruptor. The present study contributes to progress in our understanding of the molecular mechanisms of clotrimazole and its impact on testis physiology.

\section{Acknowledgments}

This work was funded by a grant of the French ministry of Ecology P189-NEMO to FB, and by the European Union LIFECYCLE projects no FP7-222719 to RWS. DB was supported by a doctoral fellowship from ANRT and INERIS. We thank Dr. Alexis Fostier (INRA, Rennes, France) for comments on the manuscript. We thank Benjamin Piccini for his technical assistance. 
Ankley GT, Jensen KM, Kahl MD, Makynen EA, Blake LS, Greene KJ, Johnson RD, Villeneuve DL (2007) Ketoconazole in the fathead minnow (Pimephales promelas): Reproductive toxicity and biological compensation. Environ Toxicol Chem 26 (6):1214-1223

Ankley GT, Kahl MD, Jensen KM, Hornung MW, Korte JJ, Makynen EA, Leino RL (2002) Evaluation of the aromatase inhibitor fadrozole in a short-term reproduction assay with the fathead minnow (Pimephales promelas). Toxicol Sci 67 (1):121-130

Ayub M, Levell MJ (1987) Inhibition of Testicular 17-Alpha-Hydroxylase and 17,20-Lyase but Not 3Beta-Hydroxysteroid Dehydrogenase-Isomerase or 17-Beta-Hydroxysteroid Oxidoreductase by Ketoconazole and Other Imidazole Drugs. J Steroid Biochem Mol Biol 28 (5):521-531. doi:10.1016/0022-4731(87)90511-5

Baudiffier D, Hinfray N, Vosges M, Creusot N, Chadili E, Porcher J-M, Schulz RW, Brion F (2012) A critical role of follicle-stimulating hormone (Fsh) in mediating the effect of clotrimazole on testicular steroidogenesis in adult zebrafish. Toxicology 298 (1-3):30-39

Berenzen N, Lentzen-Godding A, Probst M, Schulz H, Schulz R, Liess M (2005) A comparison of predicted and measured levels of runoff-related pesticide concentrations in small lowland streams on a landscape level, Chemosphere 58 (5):683-691.

Brown AR, Bickley LK, Le Page G, Hosken DJ, Paull GC, Hamilton PB, Owen SF, Robinson J, Sharpe AD, Tyler CR (2011) Are Toxicological Responses in Laboratory (Inbred) Zebrafish Representative of Those in Outbred (Wild) Populations? - A Case Study with an Endocrine Disrupting Chemical. Environ Sci Technol 45 (9):4166-4172. doi:10.1021/es200122r

Burns KH, Matzuk MM (2002) Minireview: Genetic models for the study of gonadotropin actions. Endocrinology 143 (8):2823-2835. doi:10.1210/en.143.8.2823

Chen SX, Bogerd J, Schoonen NE, Martijn J, de Waal PP, Schulz RW A progestin $(17 \alpha, 20 \beta-$ dihydroxy-4-pregnen-3-one) stimulates early stages of spermatogenesis in zebrafish. Gen Comp Endocrinol (in revision).

de Waal PP, Leal MC, Garcia-Lopez A, Liarte S, de Jonge H, Hinfray N, Brion F, Schulz RW, Bogerd J (2009) Oestrogen-induced androgen insufficiency results in a reduction of proliferation and differentiation of spermatogonia in the zebrafish testis. J Endocrinol 202 (2):287-297. doi:10.1677/joe-09-0050

de Waal PP, Wang DS, Nijenhuis WA, Schulz RW, Bogerd J (2008) Functional characterization and expression analysis of the androgen receptor in zebrafish (Danio rerio) testis. Reproduction 136 (2):225-234. doi:10.1530/rep-08-0055

Diotel N, Do Rego JL, Anglade I, Vaillant C, Pellegrini E, Gueguen MM, Mironov S, Vaudry H, Kah $\mathrm{O}$ (2011) Activity and expression of steroidogenic enzymes in the brain of adult zebrafish. Eur J Neurosci 34 (1):45-56. doi:10.1111/j.1460-9568.2011.07731.x

Feitsma H, Leal MC, Moens PB, Cuppen E, Schulz RW (2007) Mlh1 deficiency in zebrafish results in male sterility and aneuploid as well as triploid progeny in females. Genetics 175 (4):15611569. doi:10.1534/genetics.106.068171

Forlano PM, Deitcher DL, Myers DA, Bass AH (2001) Anatomical distribution and cellular basis for high levels of aromatase activity in the brain of teleost fish: Aromatase enzyme and mRNA expression identify glia as source. J Neurosci 21 (22):8943-8955

Garcia-Lopez A, Bogerd J, Granneman JCM, van Dijk W, Trant JM, Taranger GL, Schulz RW (2009) Leydig Cells Express Follicle-Stimulating Hormone Receptors in African Catfish. Endocrinology 150 (1):357-365. doi:10.1210/en.2008-0447

Garcia-Lopez A, de Jonge H, Nobrega RH, de Waal PP, van Dijk W, Hemrika W, Taranger GL, Bogerd J, Schulz RW (2010) Studies in Zebrafish Reveal Unusual Cellular Expression Patterns of Gonadotropin Receptor Messenger Ribonucleic Acids in the Testis and Unexpected Functional Differentiation of the Gonadotropins. Endocrinology 151 (5):23492360. doi:10.1210/en.2009-1227

Georgopapadakou NH (1998) Antifungals: mechanism of action and resistance, established and novel drugs. Curr Opin Microbiol 1 (5):547-557. doi:10.1016/s1369-5274(98)80087-8 
Griswold MD (1995) Interactions between Germ-Cells and Sertoli Cells in the Testis. Biol Reprod 52 (2):211-216. doi:10.1095/biolreprod52.2.211

Heneweer M, van den Berg M, Sanderson JT (2004) A comparison of human H295R and rat R2C cell lines as in vitro screening tools for effects on aromatase. Toxicol Lett 146 (2):183-194. doi:10.1016/j.toxlet.2003.10.002

Henry MJ, Sisler HD (1984) Effects of Sterol Biosynthesis-Inhibiting (Sbi) Fungicides on Cytochrome-P-450 Oxygenations in Fungi. Pestic Biochem Physiol 22 (3):262-275. doi:10.1016/0048-3575(84)90019-1

Hinfray N, Baudiffier D, Leal MC, Porcher JM, Ait-Aissa S, Le Gac F, Schulz RW, Brion F (2011) Characterization of testicular expression of P450 17 alpha-hydroxylase, 17,20-lyase in zebrafish and its perturbation by the pharmaceutical fungicide clotrimazole. Gen Comp Endocrinol 174 (3):309-317. doi:10.1016/j.ygcen.2011.09.008

Hinfray N, Palluel O, Turies C, Cousin C, Porcher JM, Brion F (2006a) Brain and gonadal aromatase as potential targets of endocrine disrupting chemicals in a model species, the zebrafish (Danio rerio). Environ Toxicol 21 (4):332-337. doi:10.1002/tox.20203

Hinfray N, Porcher JM, Brion F (2006b) Inhibition of rainbow trout (Oncorhynchus mykiss) P450 aromatase activities in brain and ovarian microsomes by various environmental substances. Comp Biochem and Physiol C-Toxicology \& Pharmacology 144 (3):252-262

Huggett J, Dheda K, Bustin S, Zumla A (2005) Real-time RT-PCR normalisation; strategies and considerations. Genes Immun 6 (4):279-284. doi:10.1038/sj.gene.6364190

Kahle M, Buerge IJ, Hauser A, Muller MD, Poiger T (2008) Azole Fungicides: Occurrence and Fate in Wastewater and Surface Waters. Environ Sci Technol 42 (19):7193-7200.

Kazeto Y, Kohara M, Miura T, Miura C, Yamaguchi S, Trant JM, Adachi S, Yamauchi K (2008) Japanese Eel Follicle-Stimulating Hormone (Fsh) and Luteinizing Hormone (Lh): Production of Biologically Active Recombinant Fsh and Lh by Drosophila S2 Cells and Their Differential Actions on the Reproductive Biology. Biol Reprod 79 (5):938-946. doi:10.1095/biolreprod.108.070052

Kobayashi M, Amano M, Kim MH, Yoshiura Y, Sohn YC, Suetake H, Aida K (1997) Gonadotropinreleasing hormone and gonadotropin in goldfish and masu salmon. Fish Physiol Biochem 17 (1-6):1-8. doi:10.1023/a:1007764430746

Kreuger J (1998) Pesticides in stream water within an agricultural catchment in southern Sweden, 1990-1996. Sci Total Environ 216 (3): 227-251.

Kumar TR (2005) What have we learned about gonadotropin function from gonadotropin subunit and receptor knockout mice? Reproduction 130 (3):293-302. doi:10.1530/rep.1.00660

Leal MC, Cardoso ER, Nobrega RH, Batlouni SR, Bogerd J, Franca LR, Schulz RW (2009) Histological and stereological evaluation of zebrafish (Danio rerio) spermatogenesis with an emphasis on spermatogonial generations. Biol Reprod 81: 177-187

Lee AJ, Cai MX, Thomas PE, Conney AH, Zhu BT (2003) Characterization of the oxidative metabolites of $17 \beta$-estradiol and estrone formed by 15 selectively expressed human cytochrome p450 isoforms. Endocrinology 144: 3382-3398

Le Roy C, Lejeune H, Chuzel F, Saez JM, Langlois D (1999) Autocrine regulation of Leydig cell differentiated functions by insulin-like growth factor I and transforming growth factor beta. $\mathbf{J}$ Steroid Biochem Mol Biol 69 (1-6):379-384. doi:10.1016/s0960-0760(99)00075-8

Loir M (1999) Spermatogonia of rainbow trout: II. In vitro study of the influence of pituitary hormones, growth factors and steroids on mitotic activity. Mol Reprod Dev 53 (4):434-442. doi:10.1002/(sici)1098-2795(199908)53:4<434::aid-mrd9>3.0.co;2-1

Lou YR, Qiao S, Talonpoika R, Syvala H, Tuohimaa P (2004) The role of vitamin D-3 metabolism in prostate cancer. J Steroid Biochem Mol Biol 92 (4):317-325. doi:10.1016/j.jsbmb.2004.10.007

Matta SLP, Vilela DAR, Godinho HP, Franca LR (2002) The goitrogen 6-n-propyl-2-thiouracil (PTU) given during testis development increases sertoli and germ cell numbers per cyst in fish: The tilapia (Oreochromis niloticus) model. Endocrinology 143 (3):970-978. doi:10.1210/en.143.3.970

McLachlan RI, O'Donnell L, Stanton PG, Balourdos G, Frydenberg M, de Kretser DM, Robertson DM (2002) Effects of testosterone plus medroxyprogesterone acetate on semen quality, 
reproductive hormones, and germ cell populations in normal young men. J Clin Endocrinol Metab 87 (2):546-556. doi:10.1210/jc.87.2.546

Menuet A, Pellegrini E, Brion F, Gueguen MM, Anglade I, Pakdel F, Kah O (2005) Expression and estrogen-dependent regulation of the zebrafish brain aromatase gene. J Comp Neurol 485 (4):304-320. doi:10.1002/cne.20497

Miller WL (1988) Molecular-Biology of Steroid-Hormone Synthesis. Endocr Rev 9 (3):295-318

Miura T, Miura C, Yamauchi K (2001a) cDNA cloning of spermatogenesis relating substances and the analysis of their functions in Japanese eel. In: Perspective in Comparative Endocrinology: Unity and Diversity. Medimond S R L, 40128 Bologna, pp 969-976

Miura T, Yamauchi K, Takahashi H, Nagahama Y (1991) Hormonal Induction of All Stages of Spermatogenesis Invitro in the Male Japanese Eel (Anguilla-Japonica). Proc Natl Acad Sci U S A 88 (13):5774-5778. doi:10.1073/pnas.88.13.5774

Monod G, Demones A, Fostier A (1993) Inhibition of Ovarian Microsomal Aromatase and Follicular Estradiol Secretion by Imidazole Fungicides in Rainbow-Trout. Mar Environ Res 35 (12):153-157

Nobrega RH, Batlouni SR, Franca LR (2009) An overview of functional and stereological evaluation of spermatogenesis and germ cell transplantation in fish. Fish Physiol Biochem 35 (1):197206. doi:10.1007/s10695-008-9252-z

Ohta T, Miyake H, Miura C, Kamei H, Aida K, Miura T (2007) Follicle-stimulating hormone induces spermatogenesis mediated by androgen production in Japanese Eel, Anguilla japonica. Biol Reprod 77 (6):970-977. doi:10.1095/biolreprod.107.062299

Parker KL, Schimmer BP (1995) Transcriptional regulation of the genes encoding the cytochrome P450 steroid hydroxylases. Vitam Horm 51:339-370

Pasmanik M, Callard GV (1985) Aromatase and 5-Alpha-Reductase in the Teleost Brain, Spinal-Cord, and Pituitary-Gland. Gen Comp Endocrinol 60 (2):244-251. doi:10.1016/00166480(85)90320-x

Peschka M, Roberts PH, Knepper TP (2007) Analysis, fate studies and monitoring of the antifungal agent clotrimazole in the aquatic environment. Anal Bioanal Chem 389 (3):959-968. doi:10.1007/s00216-007-1480-z

Petersen C, Soder O (2006) The Sertoli cell - A hormonal target and "Super" nurse for germ cells that determines testicular size. Horm Res 66 (4):153-161. doi:10.1159/000094142

Pierce JG, Parsons TF (1981) Glycoprotein Hormones - Structure and Function. Annu Rev Biochem 50:465-495. doi:10.1146/annurev.bi.50.070181.002341

Planas JV, Swanson P, Dickhoff WW (1993) Regulation of Testicular-Steroid Production in-Vitro by Gonadotropins (Gth-I and Gth-Ii) and Cyclic-Amp in Coho Salmon (Oncorhynchus-Kisutch). Gen Comp Endocrinol 91 (1):8-24. doi:10.1006/gcen.1993.1099

Plant TM, Marshall GR (2001) The functional significance of FSH in spermatogenesis and the control of its secretion in male primates. Endocr Rev 22 (6):764-786. doi:10.1210/er.22.6.764

Roberts PH, Thomas KV (2006) The occurrence of selected pharmaceuticals in wastewater effluent and surface waters of the lower Tyne catchment. Sci Total Environ 356 (1-3):143-153.

Schulz RW, de Franca LR, Lareyre JJ, Legac F, Chiarini-Garcia H, Nobrega RH, Miura T (2010) Spermatogenesis in fish. Gen Comp Endocrinol 165 (3):390-411. doi:10.1016/j.ygcen.2009.02.013

Schuster I (1985) The Interaction of Representative Members from 2 Classes of Antimycotics - the Azoles and the Allylamines - with Cytochromes-P-450 in Steroidogenic Tissues and Liver. Xenobiotica 15 (6):529-546

Steven C, Lehnen N, Kight K, Ijiri S, Klenke U, Harris WA, Zohar Y (2003) Molecular characterization of the GnRH system in zebrafish (Danio rerio): cloning of chicken GnRH-II, adult brain expression patterns and pituitary content of salmon GnRH and chicken GnRH-II. Gen Comp Endocrinol 133 (1):27-37. doi:10.1016/s0016-6480(03)00144-8

Thomas KV, Hilton MJ (2004) The occurrence of selected human pharmaceutical compounds in UK estuaries. Mar Pollut Bull 49 (5-6):436-444.

Villeneuve DL, Blake LS, Brodin JD, Greene KJ, Knoebl I, Miracle AL, Martinovic D, Ankley GT (2007a) Transcription of key genes regulating gonadal steroidogenesis in control and 
ketoconazole- or vinclozolin-exposed fathead minnows. Toxicol Sci 98 (2):395-407. doi:10.1093/toxsci/kfm124

Villeneuve DL, Miracle AL, Jensen KM, Degitz SJ, Kahl MD, Korte JJ, Greene KJ, Blake LS, Linnum AL, Ankley GT (2007b) Development of quantitative real-time PCR assays for fathead minnow (Pimephales promelas) gonadotropin beta subunit mRNAs to support endocrine disruptor research. Com Biochem and Physiol C-Toxicology \& Pharmacology 145 (2):171-183. doi:10.1016/j.cbpc.2006.11.003

Vinggaard AM, Hnida C, Breinholt V, Larsen JC (2000) Screening of selected pesticides for inhibition of CYP19 aromatase activity in vitro. Toxicol In Vitro 14 (3):227-234. doi:10.1016/s08872333(00)00018-7

Wang DS, Jiao BW, Hu CJ, Huang XG, Liu ZH, Cheng CHK (2008) Discovery of a gonad-specific IGF subtype in teleost. Biochem Biophys Res Commun 367 (2):336-341. doi:10.1016/j.bbre.2007.12.136

Zhang XW, Hecker M, Jones PD, Newsted J, Au D, Kong R, Wu RSS, Giesy JP (2008a) Responses of the medaka HPG axis PCR array and reproduction to prochloraz and ketoconazole. Environ Sci Technol 42 (17):6762-6769. doi:10.1021/es800591t 


\section{Figure caption}

Fig.1: Expression of gonadotropin receptors and of genes involved in testis steroidogenesis of adult male zebrafish following a 21 days exposure to clotrimazole. Data are presented as the fold change in gene expression relative to the control (mean $\pm \mathrm{SEM} ; \mathrm{n}=9$ - 15 fish for each condition). An asterisk indicates a significant difference compared to control group $(* \mathrm{p} \leq 0.05, * * \mathrm{p} \leq 0.01, * * * \mathrm{p} \leq 0.001)$.
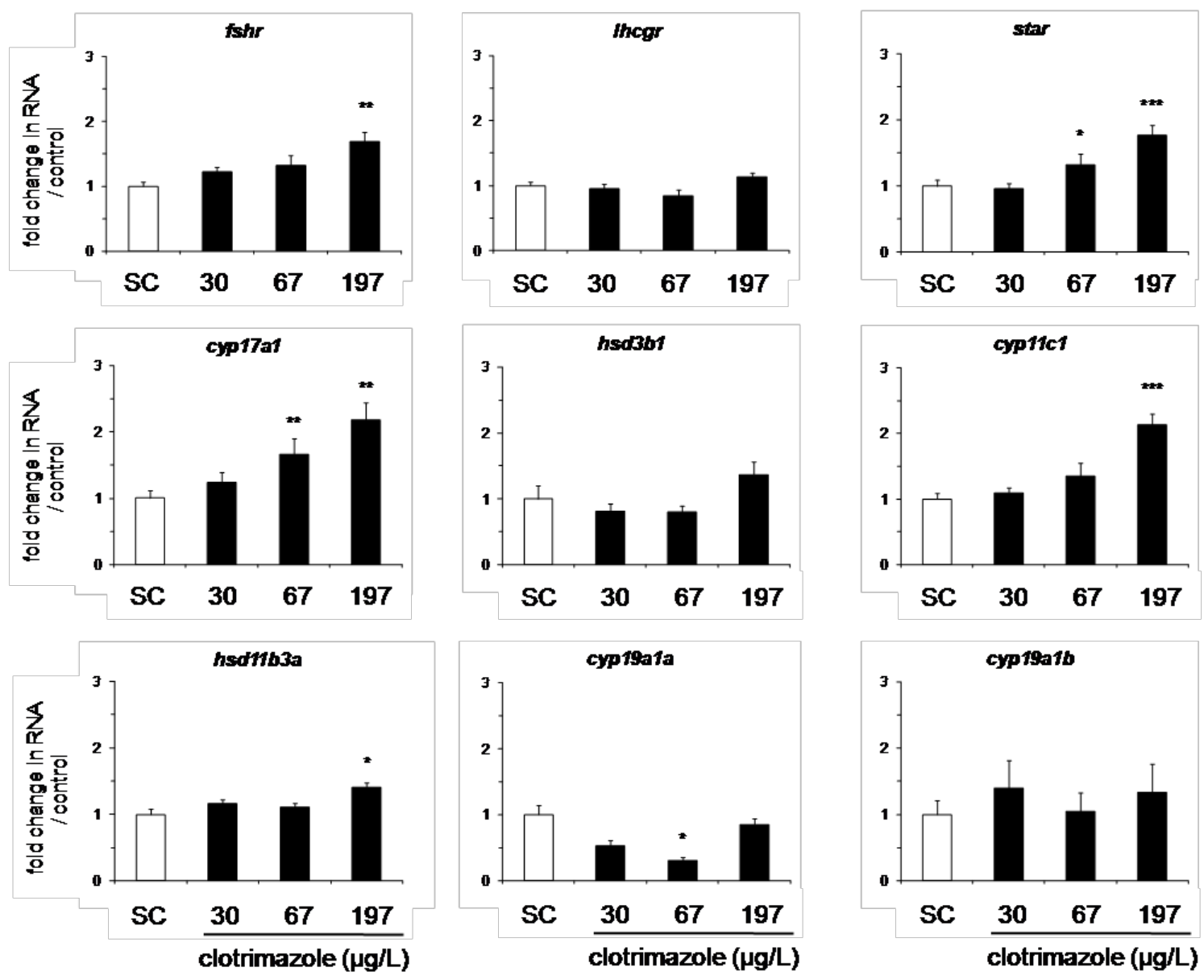
Fig.2: Expression of gonadotropins beta sub-unit genes $(f \operatorname{sh} \beta$ and $\ln \beta)$ in pituitary of adult male zebrafish following a 21 days exposure to clotrimazole $(197 \mu \mathrm{g} / \mathrm{L})$. Data are presented as the fold change in gene expression relative to the control (mean $\pm \mathrm{SEM} ; \mathrm{n}=14-18$ fish for each condition). An asterisk indicates a significant difference compared to control group $(* \mathrm{p} \leq 0.05, * * \mathrm{p} \leq 0.01)$.
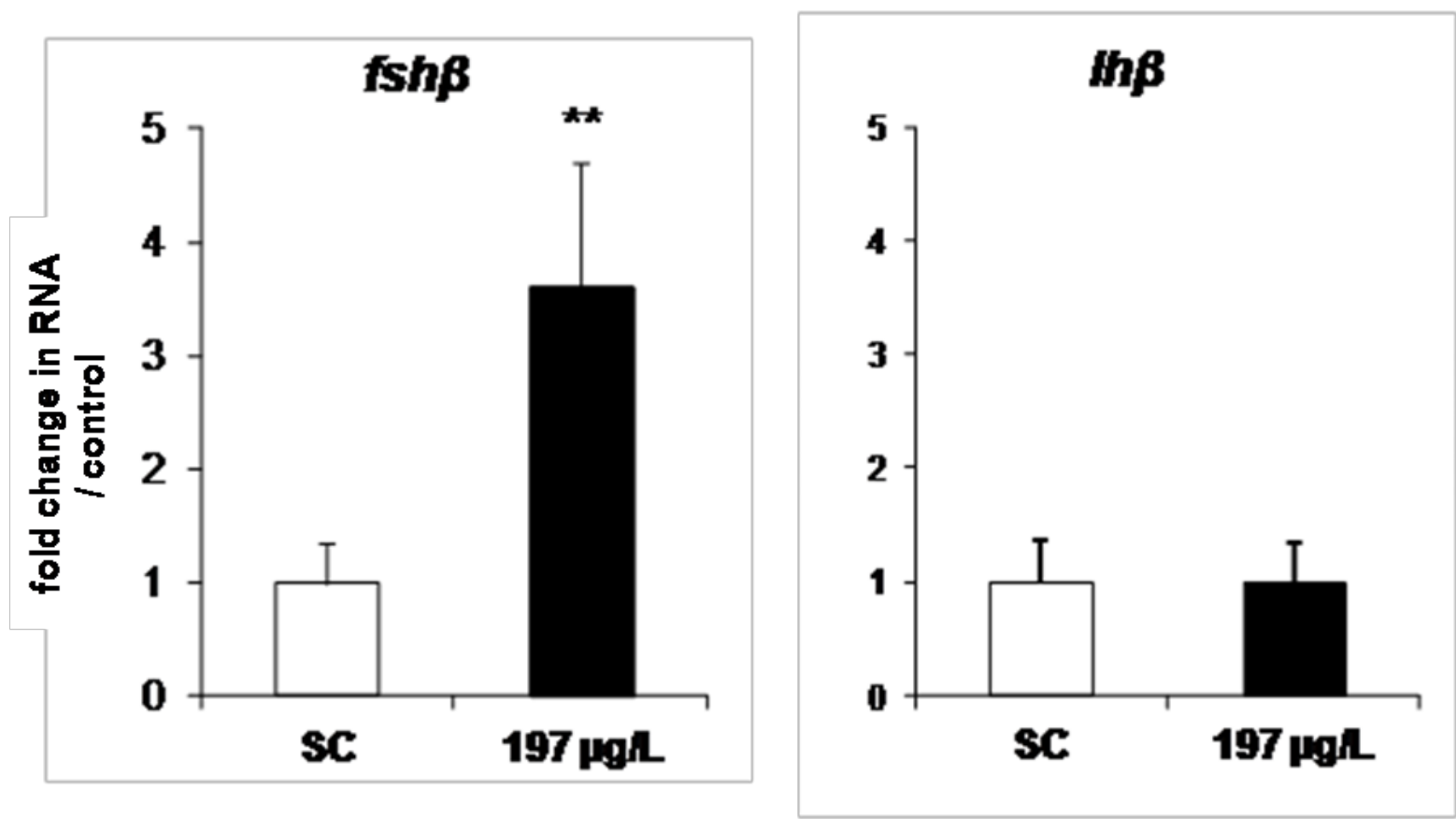
Fig.3: Change in (A) Cyp17a1 and (B) Cyp11c1 protein labelling in zebrafish testes by fluorescent immunohistochemistry after a 21 days exposure to clotrimazole. Immunoreactivity was localized in Leydig cells and observed in all groups. Red: Cyp17a1 or Cyp11c1 immunostaining, blue: Hoechst staining. $\mathrm{N}=6$ fish /condition. Pictures are representatives of the 6 individuals analyzed as regards the staining patterns. Scale Bars $=50 \mu \mathrm{m}$ (white).
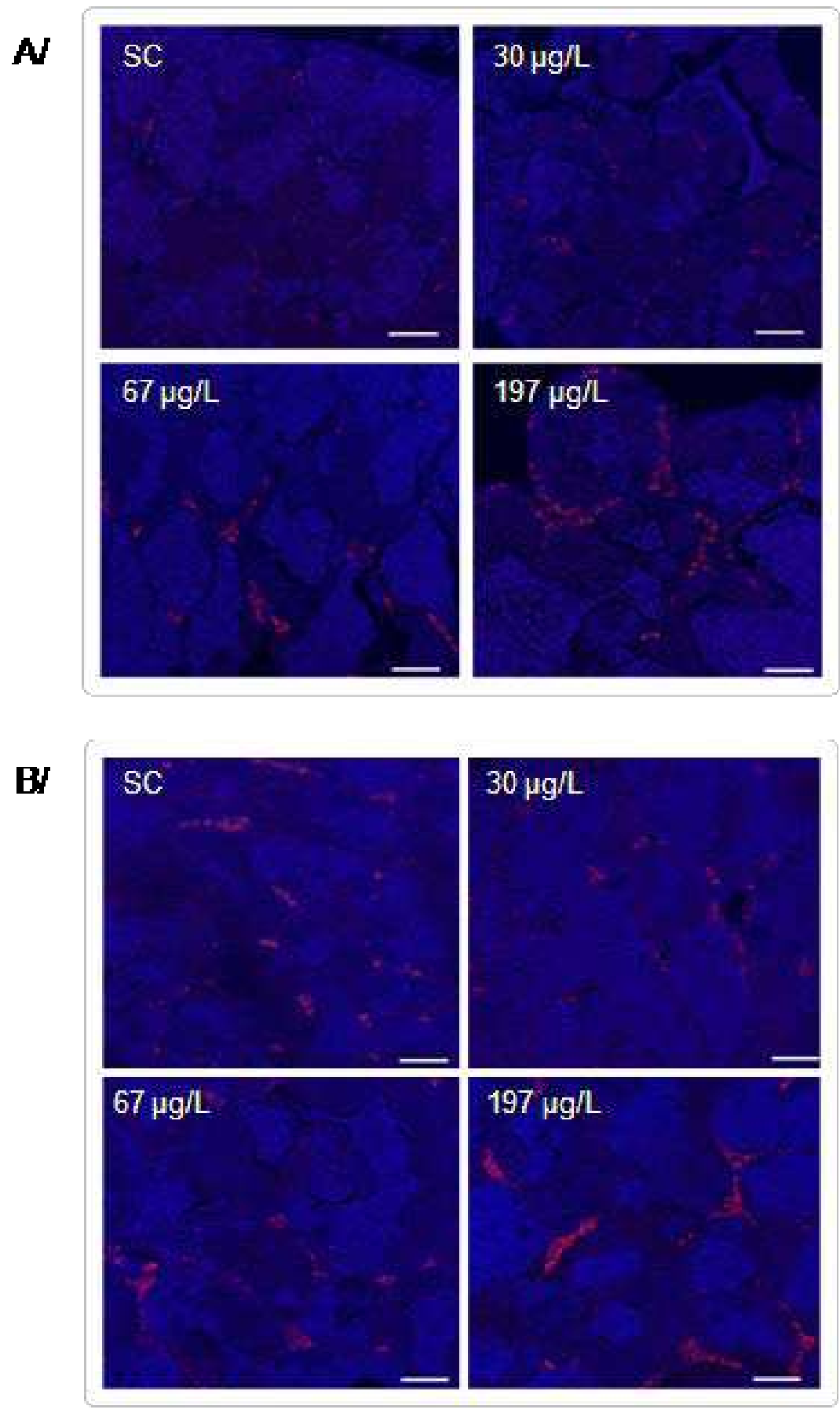
Fig.4: Plasma concentrations of 11-KT in adult male zebrafish following a 21 days exposure to clotrimazole. Data are expressed in $\mathrm{pg} / \mathrm{ml}$ (mean $\pm \mathrm{SEM} ; \mathrm{N}=15-21$ fish /condition). $11-\mathrm{KT}=11$ ketotestosterone $(* \mathrm{p} \leq$ $0.05)$

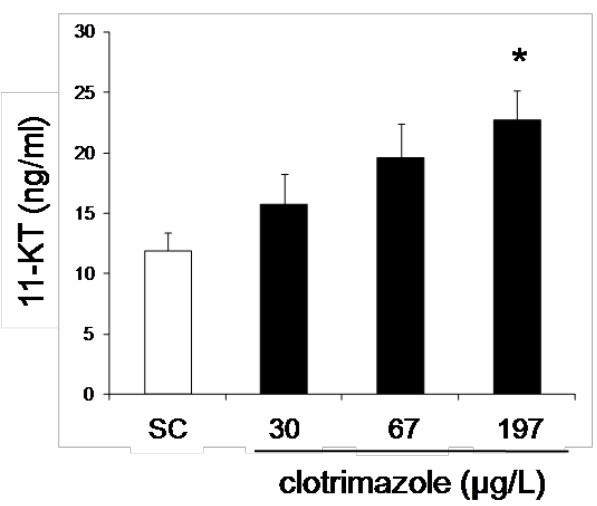

Fig. 5: Expression of Sertoli and germ cells localized-genes in testes of adult male zebrafish following a 21 days exposure to clotrimazole. Data are presented as the fold change in gene expression relative to the control (mean $\pm \mathrm{SEM}, \mathrm{n}=11-15$ fish for each condition). An asterisk indicates a significant difference compared to control group $(* \mathrm{p} \leq 0.05, * * \mathrm{p} \leq 0.01)$.
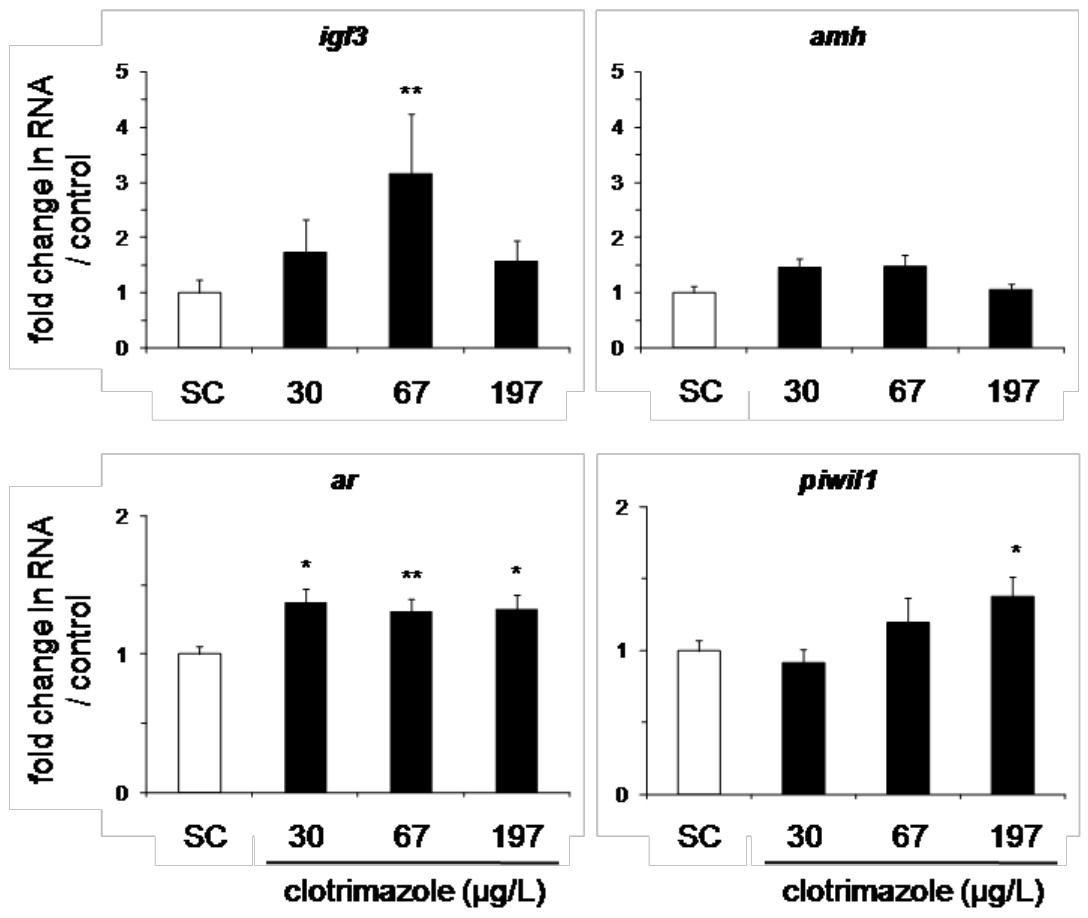
Fig.6: Principal Component Analysis (PCA) of testicular gene expressions data as well as GSI and plasma concentration of 11-KT in adult male zebrafish for control fish and clotrimazole-exposed fish: figure $6 \mathrm{~A}$ is a plot of the two dimensional PCA and figure 6B is a trajectory plot representing each treatment groups. The 95\% confidence ellipses were drawn around each group (green: solvent control, yellow: clotrimazole $28 \mu \mathrm{g} / \mathrm{L}$, brown: clotrimazole $67 \mu \mathrm{g} / \mathrm{L}$, red: clotrimazole $197 \mu \mathrm{g} / \mathrm{L})$.

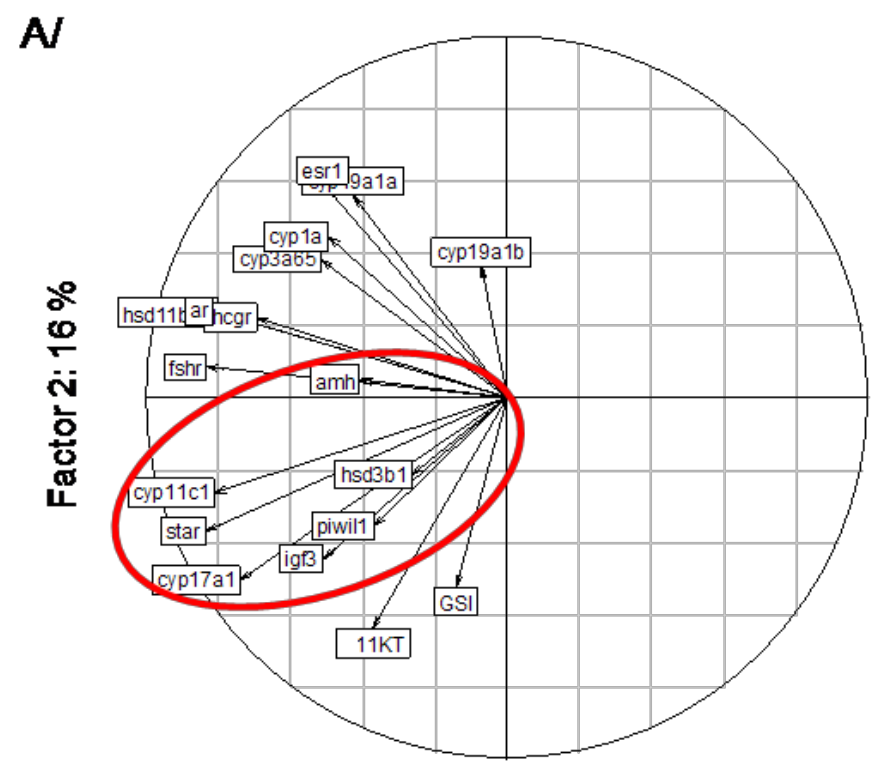

Factor 1: $34.02 \%$

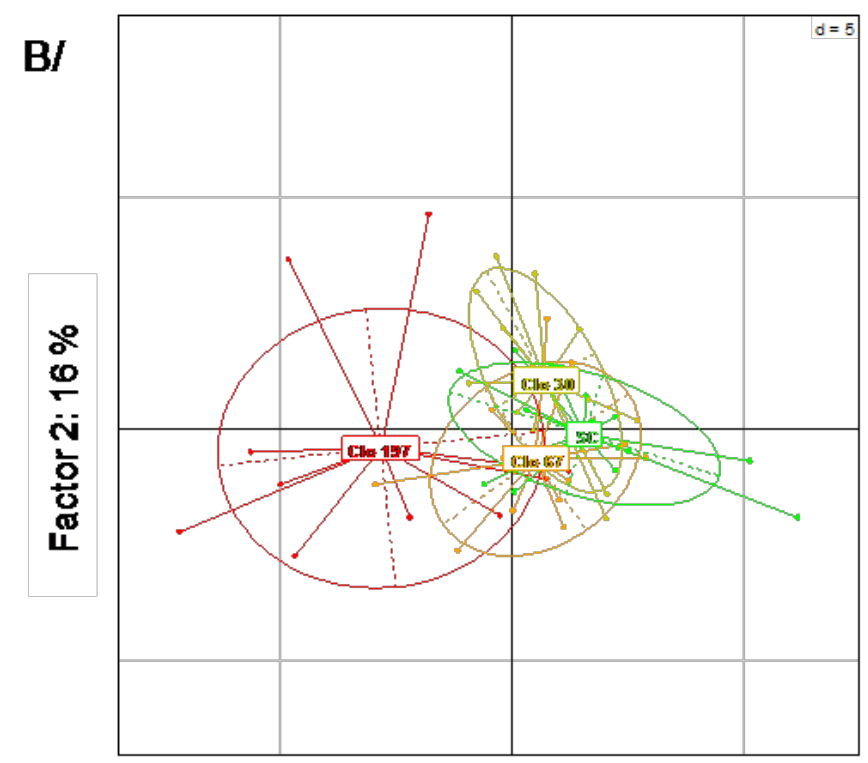

Factor 1: $34.02 \%$ 
Fig.7: Zebrafish testicular structure following a 21 days exposure to $197 \mu \mathrm{g} / \mathrm{L}$ clotrimazole: zebrafish testis sections from control fish (A), or from clotrimazole-exposed fish (B). \% of Leydig cells in testicular tissue from control fish or clotrimazole-exposed fish ( $n=3-5)(C)$. Morphometric analysis (D) of zebrafish testis sections from control group (empty white circle, $\mathrm{n}=5$ ) or from the $197 \mu \mathrm{g} / \mathrm{L}$ clotrimazole-exposed group (full dark circle, $n=6$ ) following a 21 days exposure. Data are represented as mass (mg) of testicular cell types: SPGA: spermatogonia A, SPGB: spermatogonia B, SPC: spermatocytes, SPT: spermatids, SPZ: spermatozoa and others.
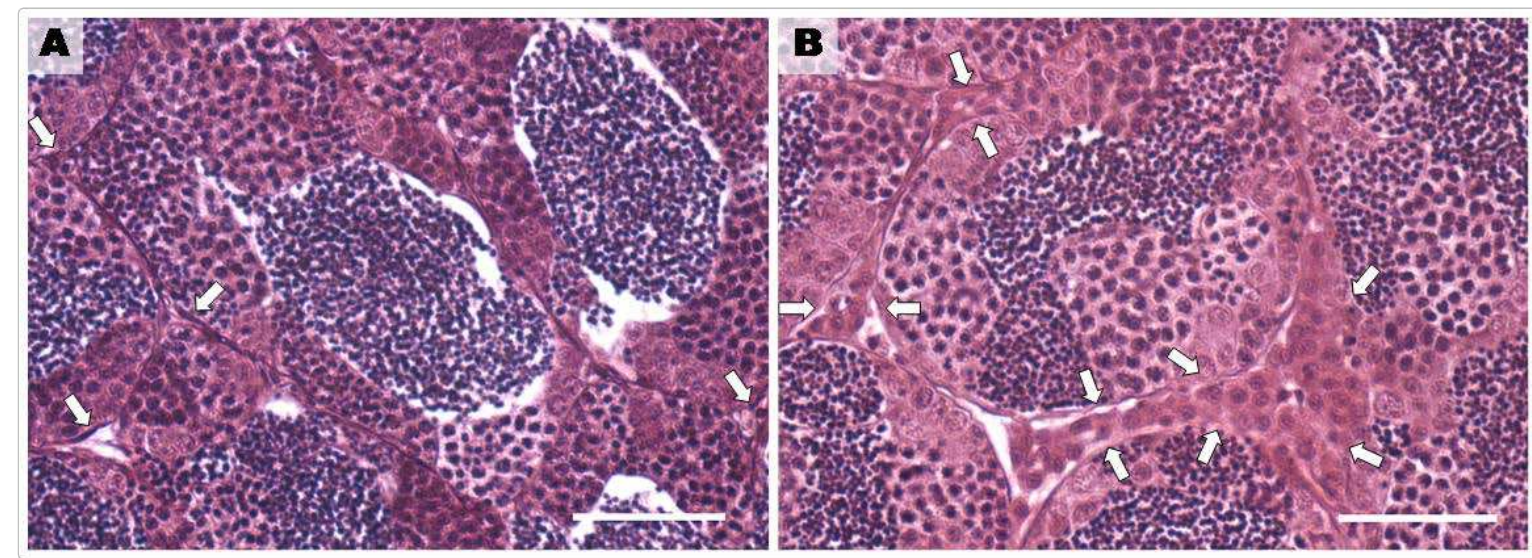

C

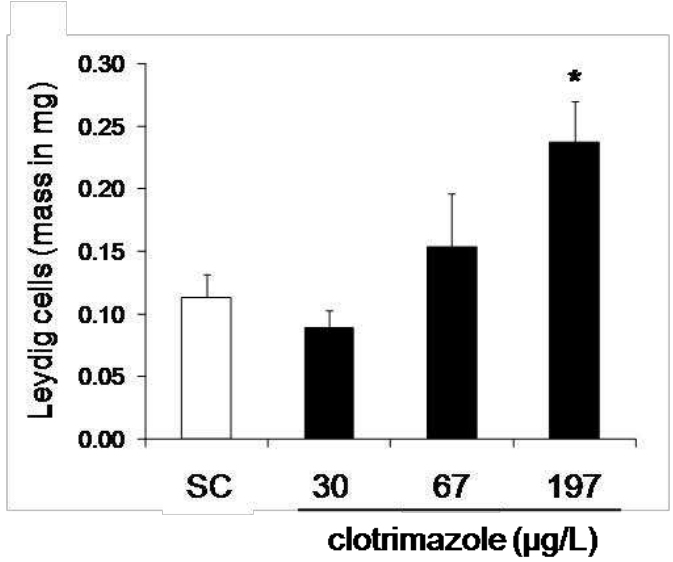

D

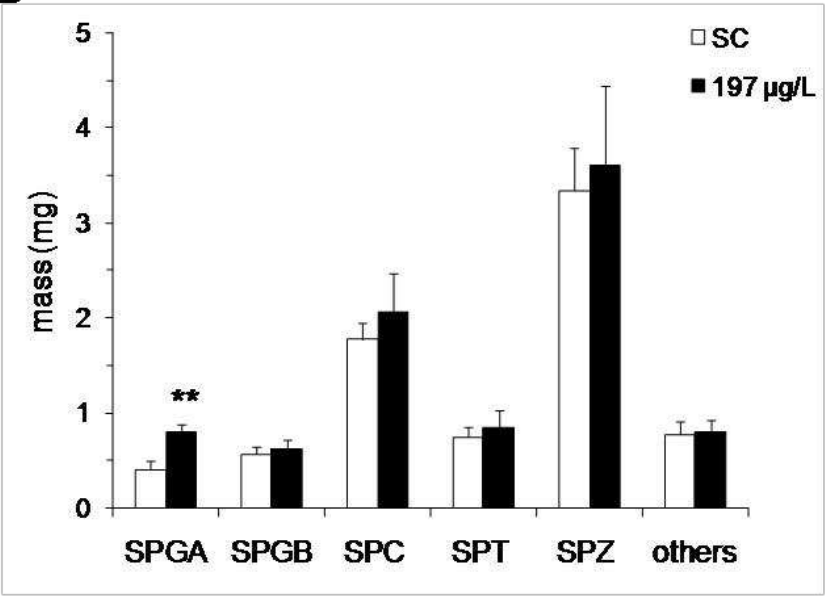


Fig.S1: Expression of phase I drug metabolizing enzymes (DMEs) and phase II conjugating enzymes genes as well as steroid receptors in the liver of adult male zebrafish following a 21 days exposure to clotrimazole. Data are presented as the fold change in gene expression relative to the control (mean $\pm \mathrm{SEM}$; $\mathrm{n}=3$ - 9 fish for each condition). An asterisk indicates a significant difference compared to control group.

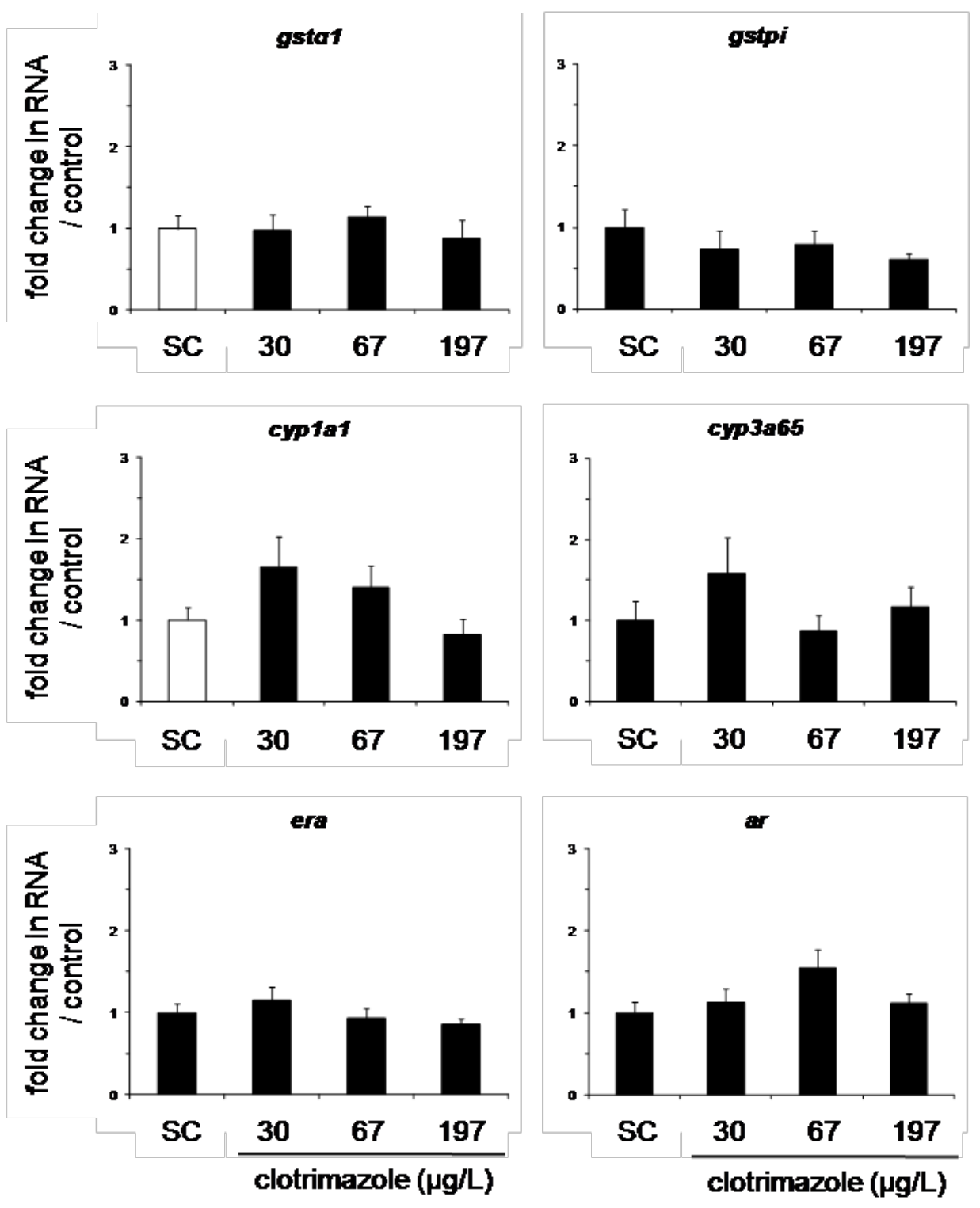


Fig.S2: Expression of drug metabolizing enzymes (DMEs) genes in testes of adult male zebrafish following a 21 days exposure to clotrimazole. Data are represented as the fold change in gene expression relative to the control (mean $\pm \mathrm{SEM} ; \mathrm{n}=9$ - 10 fish for each condition). An asterisk indicates a significant difference compared to control group $(* \mathrm{p} \leq 0.05)$.
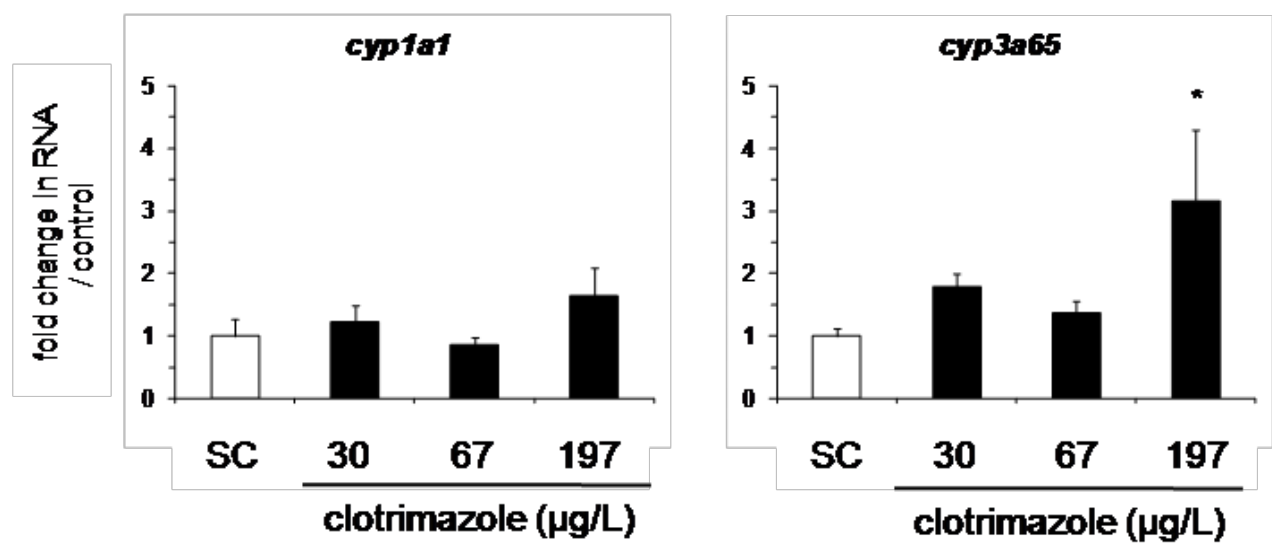
Table 1: Clotrimazole concentrations $(\mu \mathrm{g} / \mathrm{L})$ measured in water just after contamination $(\mathrm{t}=0 \mathrm{~h})$ and $24 \mathrm{~h}$ later $(\mathrm{t}=$ 24h)

\begin{tabular}{ccccc}
\hline & $\begin{array}{c}\text { Solvent } \\
\text { control }\end{array}$ & & contamination & \\
\hline & & Iow & medium & high \\
t0h & $<$ LOD & $30.2 \pm 1.6$ & $66.8 \pm 0.3$ & $197.3 \pm 6.4$ \\
t24h & $<$ LOD & $20.5 \pm 0.8$ & $55.5 \pm 7.1$ & $153.6 \pm 3.0$ \\
\hline
\end{tabular}

LOD = Limit of detection 
Table 2: Biometric parameters of fish after 21 days of chronic treatment with various concentrations of clotrimazole

\begin{tabular}{|c|c|c|c|c|c|c|}
\hline & Group & $\mathrm{N}$ & body weight (mg) & gonad weight (mg) & body lenght $(\mathrm{cm})$ & GSI (\%) \\
\hline control & solvent & 21 & $486 \pm 103$ & $8.3 \pm 4.1$ & $3.70 \pm 0.27$ & $1.6 \pm 0.5$ \\
\hline \multirow[t]{3}{*}{ clotrimazole } & low $(29 \mu g / L)^{1}$ & 20 & $513 \pm 133$ & $8.9 \pm 4.0$ & $3.82 \pm 0.27$ & $1.7 \pm 0.6$ \\
\hline & medium $(67 \mu g / L)^{1}$ & 21 & $454 \pm 133$ & $8.0 \pm 4.7$ & $3.71 \pm 0.27$ & $1.6 \pm 0.8$ \\
\hline & high $(197 \mu g / L)^{1}$ & 21 & $523 \pm 119$ & $10.3 \pm 3.9$ & $3.83 \pm 0.24$ & $2.0 \pm 0.9^{*}$ \\
\hline
\end{tabular}

\footnotetext{
${ }^{1}$ Measured concentrations just after adding clotrimazole in water

* significant difference compared to control group (ANOVA paramétrique $p \leq 0.05$ )

$\mathrm{GSI}=$ Gonado somatic index; N = number of fish
} 
Table 3: Effect of a 21 days exposure to clotrimazole on brain gene expression. Results are presented as ratio of clotrimazole-treated to control fish

\begin{tabular}{|c|c|c|c|c|c|c|c|c|c|c|c|c|}
\hline \multirow[t]{2}{*}{ Experimental groups } & \multicolumn{12}{|c|}{ genes } \\
\hline & star & $h s d 3 b 1$ & cyp17a1 & cyp11c1 & hsd11b3a & cyp19a1a & cyp19a1b & gnrh3 & ar & esr1 & $e s r 2 b$ & esr2a \\
\hline Solvent control & $1 \pm 0.20$ & $1 \pm 0.25$ & $1 \pm 0.20$ & $1 \pm 0.28$ & $1 \pm 0.23$ & $1 \pm 0.29$ & $1 \pm 0.22$ & $1 \pm 0.27$ & $1 \pm 0.10$ & $1 \pm 0.11$ & $1 \pm 0.14$ & $1 \pm 0.11$ \\
\hline Clotrimazole $30 \mu \mathrm{g} / \mathrm{L}$ & $0.99 \pm 0.17$ & $0.83 \pm 0.16$ & $0.71 \pm 0.06$ & $0.80 \pm 0.06$ & $1.32 \pm 0.23$ & $2.34 \pm 0.28$ & $1.42 \pm 0.41$ & $0.72 \pm 0.15$ & $0.84 \pm 0.06$ & $1.35 \pm 0.07$ & $0.92 \pm 0.08$ & $0.85 \pm 0.06$ \\
\hline Clotrimazole $67 \mu \mathrm{g} / \mathrm{L}$ & $1.05 \pm 0.31$ & $0.72 \pm 0.19$ & $0.64 \pm 0.10$ & $0.58 \pm 0.15$ & $1.02 \pm 0.32$ & $1.26 \pm 0.33$ & $0.86 \pm 0.40$ & $0.38 \pm 0.11$ & $0.86 \pm 0.13$ & $0.91 \pm 0.13$ & $0.84 \pm 0.12$ & $0.74 \pm 0.11$ \\
\hline Clotrimazole $197 \mu \mathrm{g} / \mathrm{L}$ & $1.28 \pm 0.06$ & $1.20 \pm 0.27$ & $1.05 \pm 0.08$ & $0.84 \pm 0.06$ & $1.07 \pm 0.17$ & $1.97 \pm 0.47$ & $0.73 \pm 0.21$ & $0.58 \pm 0.13$ & $0.99 \pm 0.06$ & $1.18 \pm 0.21$ & $1.02 \pm 0.14$ & $1.17 \pm 0.15$ \\
\hline
\end{tabular}


Table 4 : Morphometric analysis of the testes following several azole or triazole exposures and impact on GSI

\begin{tabular}{|c|c|c|c|c|c|c|c|}
\hline reference & species & azole & time of exposure & $\begin{array}{c}\text { concentration / } \\
\text { duration }\end{array}$ & steroidogenesis & $\mathrm{T} / 11-\mathrm{KT}$ & GSI and morphometric analysis of the gonads \\
\hline Brown - 2011 & zebrafish & clotrimazole & juvenile to adult & 2.9 and $43.7 \mu \mathrm{g} / \mathrm{L}$ & hsd17b3, cyp19a1a (-) & 11-KT reduced & - increase in the GSI \\
\hline & (Danio rerio) & (CYPs inhibitor) & $(37-133 \mathrm{dph})$ & (96 days) & & & $\begin{array}{l}\text { - increase in the proliferation of Leydig cells } \\
\text { - germ cell development was significantly more } \\
\text { advanced based on the proportions } \\
\text { of spermatids and spermatozoa compared with } \\
\text { spermatocytes and spermatogonia }\end{array}$ \\
\hline Hinfray - 2011 & $\begin{array}{c}\text { zebrafish } \\
\text { (Danio rerio) }\end{array}$ & $\begin{array}{l}\text { clotrimazole } \\
\text { (CYPs inhibitor) }\end{array}$ & adult & $\begin{array}{l}50-500 \mu \mathrm{g} / \mathrm{L} \\
\quad(7 \text { days })\end{array}$ & cyp17a1 (++) & 11-KT unchanged & - spermatogonia type A were observed more frequently \\
\hline Baudiffier - 2012 & $\begin{array}{c}\text { zebrafish } \\
\text { (Danio rerio) }\end{array}$ & $\begin{array}{l}\text { clotrimazole } \\
\text { (CYPs inhibitor) }\end{array}$ & adult & $\begin{array}{c}71-258 \mu \mathrm{g} / \mathrm{L} \\
(7 \text { days })\end{array}$ & $\begin{array}{c}\text { star, cyp17a1, cyp11c1 } \\
(++)\end{array}$ & 11-KT unchanged & \\
\hline Ankley - 2007 & $\begin{array}{l}\text { fathead minnow } \\
\text { (Pimephales } \\
\text { promelas) }\end{array}$ & $\begin{array}{l}\text { ketoconazole } \\
\text { (CYPs inhibitor) }\end{array}$ & adult & $\begin{array}{c}6-400 \mu \mathrm{g} / \mathrm{L} \\
(21 \text { days })\end{array}$ & $\underset{(++)}{c y p 11 a \text { and cyp17a1 }}$ & T unchanged & $\begin{array}{l}\text { - increase in the GSI } \\
\text { - marked proliferation of interstitial (Leydig) cells } \\
\text { - intesticial cells have more rounded nuclei and more } \\
\text { cytoplasm }\end{array}$ \\
\hline \multirow[t]{2}{*}{ Ankley - 2002} & $\begin{array}{l}\text { fathead minnow } \\
\text { (Pimephales } \\
\text { promelas) }\end{array}$ & $\begin{array}{l}\text { fadrozole } \\
\text { (aromatase } \\
\text { inhibitor) }\end{array}$ & adult & $\begin{array}{l}2-50 \mu \mathrm{g} / \mathrm{L} \\
\text { (21 days) }\end{array}$ & not measured & $\mathrm{T} / 11-\mathrm{KT}$ induced & $\begin{array}{l}\text { - increase in the GSI } \\
\text { - enlarged seminiferous tubule, accumulation of sperm } \\
\text { in the testes }\end{array}$ \\
\hline & & & & & & & - lack of germinal epithelium \\
\hline Panter - 2004 & $\begin{array}{l}\text { fathead minnow } \\
\text { (Pimephales } \\
\text { promelas) }\end{array}$ & $\begin{array}{l}\text { fadrozole } \\
\text { (aromatase } \\
\text { inhibitor) }\end{array}$ & adult & $\begin{array}{l}51.7-95.5 \mu \mathrm{g} / \mathrm{L} \\
\quad(21 \text { days })\end{array}$ & not measured & not measured & - increase in the GSI \\
\hline $\begin{array}{l}\text { Navarro-Martin - } \\
2009\end{array}$ & $\begin{array}{l}\text { sea bass } \\
\text { (Dicentrarchus } \\
\text { labrax) }\end{array}$ & $\begin{array}{l}\text { fadrozole } \\
\text { (aromatase } \\
\text { inhibitor) }\end{array}$ & $\begin{array}{l}\text { sexually } \\
\text { undifferentiated } \\
\text { (90-150 dph) }\end{array}$ & $\begin{array}{l}100 \mathrm{mg} \cdot \mathrm{kg}^{-1} \text { food } \\
\text { twice a day (60 days) }\end{array}$ & not measured & not measured & - increase in the GSI \\
\hline Goetz - 2009 & rat & $\begin{array}{l}\text { triadimefon } \\
\text { (CYPs inhibitor) }\end{array}$ & adult & $\begin{array}{c}126 \mathrm{mg} / \mathrm{kg} \text { body } \\
\text { weight/day } \\
\text { (30 days) }\end{array}$ & not measured & $\begin{array}{l}\text { T induced } \\
\text { (plasma and intra- } \\
\text { testicular) }\end{array}$ & - no change in the gonad weight \\
\hline Turner - 2000 & rat & anastrozole & adult & $200 \mathrm{mg} / \mathrm{L}$ & not measured & $\mathrm{T}$ induced & - increase in the GSI \\
\hline
\end{tabular}


(aromatase

inhibitor)

(63 days) (plasma and intratesticular)

spermatogenesis was grossly norma

$10 \%$ of rats had testes that appeared to contain only Sertoli cells

GSI: Gonado Somatic Index; $d p h$ : days post hatch 
Table S1: primer sequences of target genes

\begin{tabular}{|c|c|c|c|}
\hline Name & forward primer sequence $\left(5^{\prime}-->3^{\prime}\right)$ & reverse primer sequence $\left(5^{\prime}-->3^{\prime}\right)$ & accession number \\
\hline star & ACCTGTTTTCTGGCTGGGATG & GGGTCCATTCTCAGCCCTTAC & NM 131663 \\
\hline$h s d 3 b 1$ & GCAACTCTGGTTTTCCACACTG & CAGCAGGAGCCGTGTAGCTT & NM_212797.1 \\
\hline сур17a1 & GGGAGGCCACGGACTGTTA & CCATGTGGAACTGTAGTCAGCAA & NM_212806.3 \\
\hline cyp11c1 & GCTCATGCACATTCTGAGGA & TGTGCTGAAGGTGATTCTCG & DQ650710.1 \\
\hline hsd11b3a & TGGTGAAGTATGCCATCGAA & AGTAGCCATCGTGTGTGCTG & AY578180 \\
\hline cyp19a1a & CTGAAAGGGCTCAGGACAA & TGGTCGATGGTGTCTGATG & AF 226620 \\
\hline cyp19a1b & ACTAAGCAAGTCCTCCGCTGTGTACC & TTTAAACATACCTATGCATTGCAGACC & NM_131642.1 \\
\hline $\operatorname{lh} \beta$ & GCAGAGACACTTACAACAGCC & AAAACCAAGCTCTGAGCAGCC & NM_205622.2 \\
\hline$f \operatorname{sh} \beta$ & CAGATGAGGATGCGTGTGC & ACCCCTGCAGGACAGCC & NM_205624.1 \\
\hline Ihcgr & АTCACTCACGCTCTCCGACT & GCTGCTGACGCCTATTAAGG & NM_205625.1 \\
\hline fshr & GAGGATTCCCAGTAATGCTTTCCT & TCTATCTCACGAATCCCGTTCTTC & NM_001001812.1 \\
\hline ar & ACGTGCCTGGCGTGAAAA & CAAACCTGCCATCCGTGAAC & NM_001083123.1 \\
\hline esr1 & GGAGATGCTGGACGCTCA & GCTGCAGCTCCTCCTCTTGG & NM_152959.1 \\
\hline$e s r 2 b$ & TGATCCTGCTCAACTCTAATAAC & TCCAGCAGATTCAGCACCTTCCC & NM_174862.3 \\
\hline esr2a & TGATCCTCCTGAACTCCAACA & TCCAGCAGACACAGCAGCTTGGA & NM_180966.2 \\
\hline$a m h$ & CTCTGACCTTGATGAGCCTCATTT & GGATGTCCCTTAAGAACTTTTGCA & NM_001007779.1 \\
\hline igf3 & GTGCTGCGTTCTCATCCT & TGTTGAGGAGGTTTGGGT & NM_001115050 \\
\hline piwil1 & CAAAATGGGAGGAGAGCTGTG & CAAAGAATCGGGAGCTGATGC & NM_183338.1 \\
\hline cyp1a1 & GACAGGCGCTCCTAAAACAG & CTGAACGCCAGACTCTTTCC & NM_131879.1 \\
\hline сур3а65 & CGGTGCGTACAGTATGGATG & AGAGAGGGTTCAGCAGGTCA & NM_001037438.1 \\
\hline gstal & CGCAGGAAAATACAACCTCTATG & AGCTTCCAGAAGATGAACATCAG & NM_213394.1 \\
\hline gstp1 & CAGTTGCCTAAATTTGAAGATGG & AGCTTCCAGAAGATGAACATCAG & NM_131734.3 \\
\hline gnrh3 & AAATGGAGGCAACATTCAGG & ССTTCAGCATCCACCTCATT & NM_182887.2 \\
\hline
\end{tabular}

